\title{
PHOSPHORUS AVAILABILITY AND ALGAL PRODUCTION \\ IN WASTE WATER
}

\author{
A Thes is \\ Presented to \\ The Faculty of the Graduate School of \\ The University of Missouri \\ Columbia, Missouri \\ In Partial Fulfillment \\ of the Requirements for the Degree \\ Master of Science in Sanitary Engineering \\ by
}

Ronald Allan Vogel

August 1971 
The undersigned, appointed by the Dean of the Graduate Faculty, have examined a thesis entitled Phosphorus Availability and Algal Production in Waste Water

presented by Ronald Allan Vogul

a candidate for the degree of Master of Science in Sanitary Engineering and hereby certify that in their opinion it is worthy of acceptance.

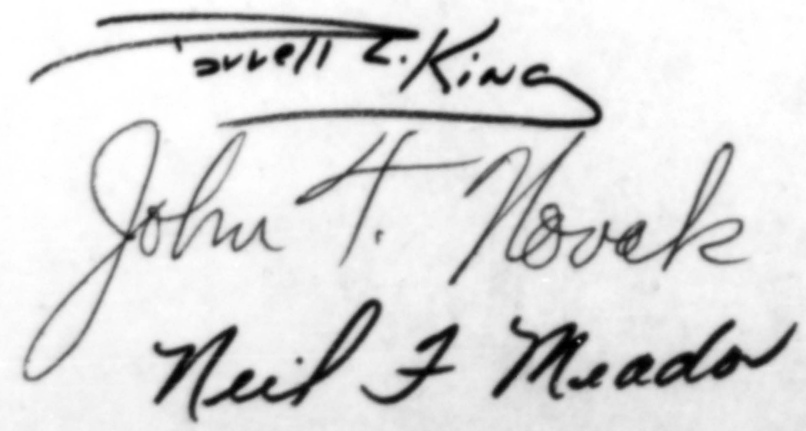




\section{ACKNOWLEDGEMENT}

I would like to express my deepest gratitude to my advisor,

Dr. Darrell L. King, for his encouragement, guidance, assistance and patience throughout this study.

I would also like to express my appreciation to the United States Air Force for financing my graduate study through their AFIT program. 


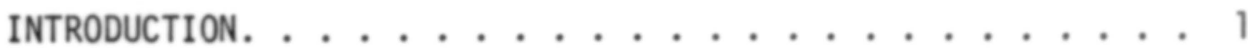

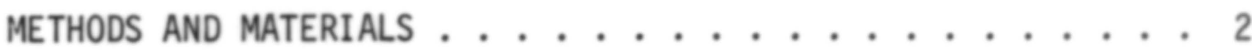

Glassware Preparation ............ . 2

Source and Preparation of Sample. . . . . . . . . 2

Media ................... 3

Description of Lake Microcosms. . . . . . . . . . . . 3

Measured Parameters . . . . . . . . . . . . . . 4

pH Measurements. . . . . . . . . . . . . 4

Carbon Budget. . . . . . . . . . . . . 4

Phytopigment Determination .......... 5

Phosphorus Budget.............. 6

Number of Measurements. . . . . . . . . . . . . 7

Phos phorus Measurements. .......... 7

Carbon Budget and pH ........... 7

Phytopigment Determination ......... 7

RESULTS AND DISCUSSION. .............. 8

Carbon Calculations ................. 10

Alkalinity .........................

Carbon Fixed Calculations............. 16

Phosphorus Calculations ............ 27

Carbon to Phosphorus Ratios ........... 30

Optimum Carbon to Phosphorus Ratio ........ 32 
Page

Algal Cell Conversion Efficiency .......... . 46

Algal Growth Potential. . . . . . . . . . . . 48

Growth Potential With Regards to Phosphorus

Removal Method................ . 48

CONCLUSIONS ............................ 50

REFERENCES. . . . . . . . . . . . . . . . 52

APPENDIX. . . . . . . . . . . . . . . . . 54 


\section{LIST OF FIGURES}

Figure

1 Phytopigment variation versus time for different dilutions of final effluent utilizing alum to remove phosphorus............... 1

2 Variation in $\mathrm{pH}$ versus time for different dilutions of final effluent utilizing alum to remove phosphorus.

3 Variation in total carbon and total organic carbon versus time for different dilutions of final effluent utilizing alum to remove phosphorus ...

4 Variation in particulate organic carbon versus time for different dilutions of final effluent utilizing alum to remove phosphorus. . . . . . . 14

5 Variations in alkalinity versus time for different dilutions of final effluent with no phosphorus removal ..............

6 Variation in alkalinity versus time for different dilutions of final effluent utilizing alum

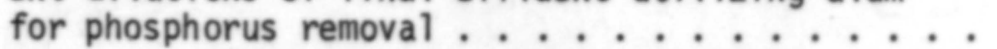

7 Variation in alkalinity versus time for different dilutions of final effluent utilizing iron for phosphorus removal ............

8 Variations in alkalinity versus time for different dilutions of final effluent utilizing lime for phosphorus removal ........... 20

9 Comparison of calculated organic carbon fixed to measured particulate organic carbon ......

10 Comparison of theoretical phosphorus uptake and orthophosphorus uptake ............

11 Maximum calculated organic carbon fixed versus maximum phytopigments for each culture 
12 Maximum measured particulate organic carbon versus maximum phytopigments for each culture . . . 35

13 Orthophosphorus uptake versus maximum phytopigments for each culture . . . . . . . . . 36

14 Maximum phytopigments versus the $C_{F}: P$ ratio for each algal culture. . . . . . . . . . 38

15 Maximum phytopigments versus the $C_{P}: P$ ratio for each algal culture. . . . . . . . . . . 39

16 Orthophosphorus uptake versus the $C_{F}: P$ ratio for each algal culture. . . . . . . . . . 40

17 Orthophosphorus uptake versus the $C_{p}: P$ ratio for each algal culture. . . . . . . . . . 41

18 The leakage of the algal cultures for different phosphorus uptake concentrations. . . . . . 45

19 The conversion efficiency of the algal cultures for different phosphorus uptake concentrations. . . 47 


\section{LIST OF TABLES}

Table

1 Non-biodegradable organic carbon in each

algal culture ................. . . 23

2 Ratio of maximum measured dissolved organic carbon to maximum measured total organic carbon. . . . . . . 26

3 Phosphorus removal and phosphorus removal efficiencies .............. . . . 28

4 Calculated carbon fixed to orthophosphorus uptake ratios and measured particulate organic carbon to orthophosphorus uptake ratios. ........ 31

5 Summary of optimum C:P ratios. . . . . . . . 43 


\section{INTRODUCTION}

Much attention has been focused recently on the role of phosphorus in the process of eutrophication. Phosphorus as discharged in effluents from waste treatment facilities has been blamed for many eutrophication problems because of $i$ ts stimulation of algal production. Tertiary treatment for phosphorus removal has been or soon will be installed in many waste treatment facilities. Therefore it is important to understand the effect that waste effluent phosphorus has on algae production.

Potential algal production due to phosphorus, however, has been difficult to evaluate because of the wide range of published carbon to phosphorus ratios for algae. Lawrence's data (1) indicate carbon to phosphorus ratios, based on atomic weight, varying from $C_{105}: P_{1}$ to $C_{1291}: P_{1}$ while Gerloff's data (2) suggests a $\mathrm{C}_{1000}: \mathrm{P}_{1}$ ratio for Microcystis. The variability of published carton to phosphorus ratios along with the ability of algae to store excess phosphorus (2)(3) suggest a variable carbon to phosphorus ratio in an algal cell.

The primary purpose of this research was to establish the algal growth potential of phosphorus laden effluent with respect to the phosphorus needs of algae. To accomplish this, an optimum carbon to phosphorus ratio had to be determined for algae. A secondary purpose of this investigation was to evaluate possible differences in algal production potential associated with different methods of phosphorus removal. 
METHODS AND MATERIALS

\section{Glassware Preparation}

All glassware utilized in this investigation was rinsed with tap water, rinsed with dicromate acid cleaning solution (4), and rinsed with distilled water. It was then soaked for twenty-four hours in a one to one $\mathrm{HCl}$ solution and rinsed three times with distilled water.

\section{Source and Preparation of Final Effluent Sample}

Final sewage effluent was obtained from the Columbia, Missouri Trickling Filter Municipal Waste Treatment Plant located in the Southwest portion of the city near the junction of Hinkson Creek and Flat Branch Creek. The effluent was collected at the discharge pipe of the final clarifier. Three liters of the effluent were placed in each of four 4 liter beakers, with Beaker No. 1 receiving no treatment and remaining as the control. The other three beakers were subjected to phosphorus removal. The chemicals and dosage for phosphorus removal are indicated as follows:

\begin{tabular}{ccc}
\hline Beaker No. & Chemical & $\begin{array}{c}\text { Dose } \\
\mathrm{mg} / 1 \text { iter }\end{array}$ \\
\hline 1 (control) & - & - \\
2 & $\mathrm{Al}_{2}\left(\mathrm{SO}_{4}\right)_{3}-8 \mathrm{H}_{2} \mathrm{O}$ & 120 \\
3 & $\mathrm{FeCl}_{3}$ & 65 \\
4 & $\mathrm{Ca}(\mathrm{OH})_{2}$ & 100 \\
\hline
\end{tabular}


Each beaker was stirred vigorously for three minutes after addition of the chemicals and allowed to settle for thirty minutes. Because the floc floated or did not readily settle, the contents of each beaker were filtered through Sargent-Welch $35 \mathrm{~mm}$ Seitz filters under a vaccum of $25 \mathrm{psig.} \mathrm{This} \mathrm{filtration} \mathrm{had} \mathrm{the} \mathrm{secondary} \mathrm{effect}$ of removing the total particulate fraction from the samples. Beaker No. 4, which had been lime treated, was then aerated for 13 hours to recarbonate the sample and lower the $\mathrm{pH}$.

Media

The media utilized in this investigation is a modification of Keveran and Ball's (5) inorganic growth media. Appendix I lists the constituents of the media with the modifications used in this study. All nutrients, with the exception of phosphorus, were present in excess amounts. Phosphorus availability was controlled by the amount of effluent added to the media. The media also contained five milligrams of ethylenediaminetetracetic acid (EDTA) per liter as a chelator to insure the ready availability of trace nutrients to the algae.

\section{Description of Experimental Lake Microcosms}

Dilutions of one to one, one to nine, and one to ninety-nine of filtered effluent to media were prepared in three one liter Erlenmeyer flasks. A fourth flask contained straight final effluent. This procedure was followed for each of the other three methods of phosphorus 
removal with three flasks containing dilutions and the fourth containing a straight treated effluent. The sixteen flasks were stoppered with rubber corks containing one half inch holes plugged with rubber serum caps. The corks were removed when samples were withdrawn, exposing the contents of the flasks to the atmosphere.

A mixed culture of green algae, consisting of Chlorella, Scendesmus, and Öocystis with Chlorella dominating, was phosphorus starved for two weeks in the media described in Appendix I. One milliliter of algal culture was used to seed each of the flasks.

Artificial lighting was supplied on a continuous basis by four 40 watt Sylvania Gro-lux flourescent lights placed over the flasks. White paper was placed under the flasks to provide the maximum possible amount of light to each culture. The lamps were arranged to furnish all flasks with equal lighting.

\section{Measured Parameters}

$\mathrm{pH}$ Measurements. Determinations of the $\mathrm{pH}$ were obtained with a Fisher Accumet Model 320 Expanded Scale pH meter. After vigorously shaking the flask, the $\mathrm{pH}$ electrode was placed directly in the flask and the value recorded.

Carbon Budget. A11 carbon analyses were performed with a Beckman (Model IR 315) Infrared Carbonaceous Analyzer. Total carbon, total organic carbon, and dissolved organic carbon were determined with the analyzer. Total carbon was measured directly after vigor- 
ously shaking the flask to obtain a homogeneous suspension by extracting a 20 microliter sample, and injecting that sample into the analyzer.

The measurement of total organic carbon and dissolved organic carbon was a more involved process. After vigorously shaking the flask, a five milliliter sample of the algal culture was extracted with a hypodermic syringe and injected into a test tube. Inorganic carbon was removed by acidifying the sample with $\mathrm{HCl}$ to a $\mathrm{pH}$ of two and scrubbing it with nitrogen gas for five minutes. Total organic carbon was then measured by injecting a twenty microliter sample of the acidified portion into the analyzer. Dissolved organic carbon was determined by filtering a five milliliter sample through a Sietz filter apparatus and following the same procedure with the filtrate as was used for total organic carbon. Subtraction of total organic carbon from total carbon gives total inorganic carbon. The difference between total organic carbon and dissolved organic carbon is particulate organic carbon.

Phytopigment Determination. The amount of phytopigments present was used as an indication of photosynthetic activity in the algal cultures. The determination is colorimetric in nature and is based on the ability of ethanol to extract chlorophyll from algal cells. The actual measurement consisted of vigorously shaking the flask, extracting five milliliters of sample from the flask with a hypodermic syringe, placing the five milliliters into a centrifuge tube, and centrifuging. After five minutes of centrifuging, the 
water was poured off and two and one half milliliters of ethanol were injected into the centrifuge tube. The tube was then corked and allowed to set for forty-eight hours. At the end of this period the two and one half milliliter sample was again centrifuged to remove cellular particulate material. The liquid portion in the centrifuge tube was then transferred to a ten milliliter volumetric flask where it was diluted to ten milliliters with ethanol. A Beckman Model D.B. Prism Spectrophotometer was employed to determine the percent transmission of the sample utilizing a wavelength of $440 \mathrm{m \mu}$, the absorbance maxima of the phytopigment extract.

Phosphorus Budget. Total phosphorus, total dissolved phosphorus, and dissolved orthophosphorus were determined by the single reagent method proposed by the FWPCA (6). Since this test is only applicable at phosphorus concentrations less than $0.5 \mathrm{mg} P / 1 \mathrm{iter}$, it was necessary to dilute the samples having higher phosphorus concentrations.

Samples for the measurement of total dissolved phosphorus and dissolved orthophosphorus were obtained by filtering aliquots of the algal cultures taken directly from the flasks through a Sietz filter apparatus. Although the FWPCA method calls for samples to be read at a wavelength of $880 \mathrm{~m} \mu$ on the spectrophotometer, the Beckman Model D.B. Prism Spectrophotometer utilized had a maximum wavelength capacity of $740 \mathrm{m \mu}$. This wavelength was employed for all phosphorus measurements and to construct a standard curve. Any errors incurred because of the discrepancy in wavelength should have been minimized since a constant wavelength was used throughout the study. 
Number of Measurements

Phosphorus Measurements. An initial orthophosphorus test was made on the filtered final effluent to insure a suitable phosphorus concentration for this investigation. The following day total phosphorus and orthophosphorus measurements were made on the straight effluent and the three effluents which had been subjected to a phosphorus removal to determine removal efficiency. Two days after collecting the effluent and one day after the dilutions had been made, total phosphorus and orthophosphorus measurements were made on all sixteen flasks to determine initial phosphorus conditions. Total phosphorus, total dissolved phosphorus and dissolved orthophosphorus tests were made on all flasks after substantial algal production became apparent, and after maximum algal production had been achieved.

Carbon Budget and $\mathrm{pH}$ Determination. The entire carbon budget and $\mathrm{pH}$ determinations were obtained every two days to determine algal growth characteristics and maximum algal production.

Phytopigment Determination. The phytopigment concentration of the algal cultures was estimated at two day intervals to determine both relative photosynthetic activity and peak photosynthetic activity. 


\section{RESULTS AND DISCUSSION}

This study represents an attempt to evaluate algal growth potential of a municipal waste effluent before and after phosphorus removal.

The investigation was accomplished by diluting final filtered effluent and final filtered effluent treated with alum, iron, and lime to remove phosphorus with a media of known alkalinity containing no phosphorus. Because the three methods of phosphorus removal yielded varying results, the phosphorus concentrations in the individual flasks showed considerable variation. From a maximum concentration of $6.86 \mathrm{mg}$ total phosphorus/liter in the untreated straight effluent, the phosphorus concentrations ranged to $26 \mu \mathrm{g}$ total phosphorus/liter in the flask containing alum treated effluent diluted one to ninety-nine with media.

Bicarbonate-carbonate alkalinity also differed among the flasks. The media had a constant alkalinity of $100 \mathrm{mg} / 1$ iter as $\mathrm{CaCO}_{3}$ and the effluent had an alkalinity of about $270 \mathrm{mg} / 1 \mathrm{iter}$ as $\mathrm{CaCO}_{3}$. The treatment for phosphorus removal had a varying effect on the alkalinity of the final effluent. Alum and iron treatment tended to decrease the alkalinity a negligible amount. However, lime treatment with recarbonation increased the alkalinity of the final effluent approximately twenty-five percent. Consequently, the inorganic carbon available to the algae varied greatly among the different flasks. 
The initial inorganic carbon in the straight filtered effluent was $67 \mathrm{mg} \mathrm{C} / 1$ iter while the initial inorganic carbon concentration in the flask containing alum treated final effluent, diluted one to ninety-nine with media, was $33 \mathrm{mg} \mathrm{C} / 1$ iter.

Stumm and Morgan (7) have stated that algae have a carbon to phosphorus ratio on an atomic weight basis of about $\mathrm{C}_{106}: \mathrm{P}_{1}$. Calculated C:P ratios, based on the data derived from this investigation, range from $C_{1.3}: P_{1}$ to $C_{2030}: P_{1}$. However, the $C_{1.3}: P_{1}$ value is sus picious because the low total algal productivity in this flask, containing untreated straight effluent, appeared to indicate inhibition of the algae. Nevertheless the large variability in C:P ratios demonstrate that a constant $C: P$ ratio for a particular species of algae does not exist.

Because of the variability of phosphorus concentrations and alkalinity, carbon limits were reached in some flasks while phosphorus limits were reached in other flasks. For these reasons, evaluation of algal growth potential cannot be related to either carbon or phosphorus availability until the relative limits of carbon and phosphorus have been established for these algae. Therefore potential algal production of the effluent used in this investigation will be based on the availability of carbon and phosphorus relative to the needs of the algae.

A11 data used in this investigation were obtained from phytopigment, pH, carbon budget and phosphorus budget determinations. Phytopigment, pH, and carbon budget determinations were measured on ail 
sixteen flasks at two day intervals. Typical examples of these data plotted against time are shown in Figures 1, 2, 3, and 4 for the different dilutions of alum treated effluent. Exact relationships are difficult to ascertain from the raw data but all of the following calculations are based on these data and similar data for the other twelve flasks.

\section{Carbon Calculations}

Because carbon is the primary element found in algae, it is probably the best measurement of algal production. According to King (8) the three possible sources of carbon for algae are the atmosphere, the bicarbonate-carbonate alkalinity system, and the degradation of organic carbon to carbon dioxide by bacteria. Data from this study revealed relatively constant total carbon concentrations in each individual flask for the entire exposure period, even though the flask contents were exposed to the atmosphere when samples were withdrawn. This suggests there was little gain of carbon from the atmosphere. Therefore the algae in this study derived carbon from the bicarbonate-carbonate alkalinity system and the bacterial degradation of the slight amount of organic carbon introduced with the final effluent.

Alkalinity. The total bicarbonate-carbonate alkalinity was calculated after determining the inorganic carbon from the data. Inorganic carbon is equal to: 


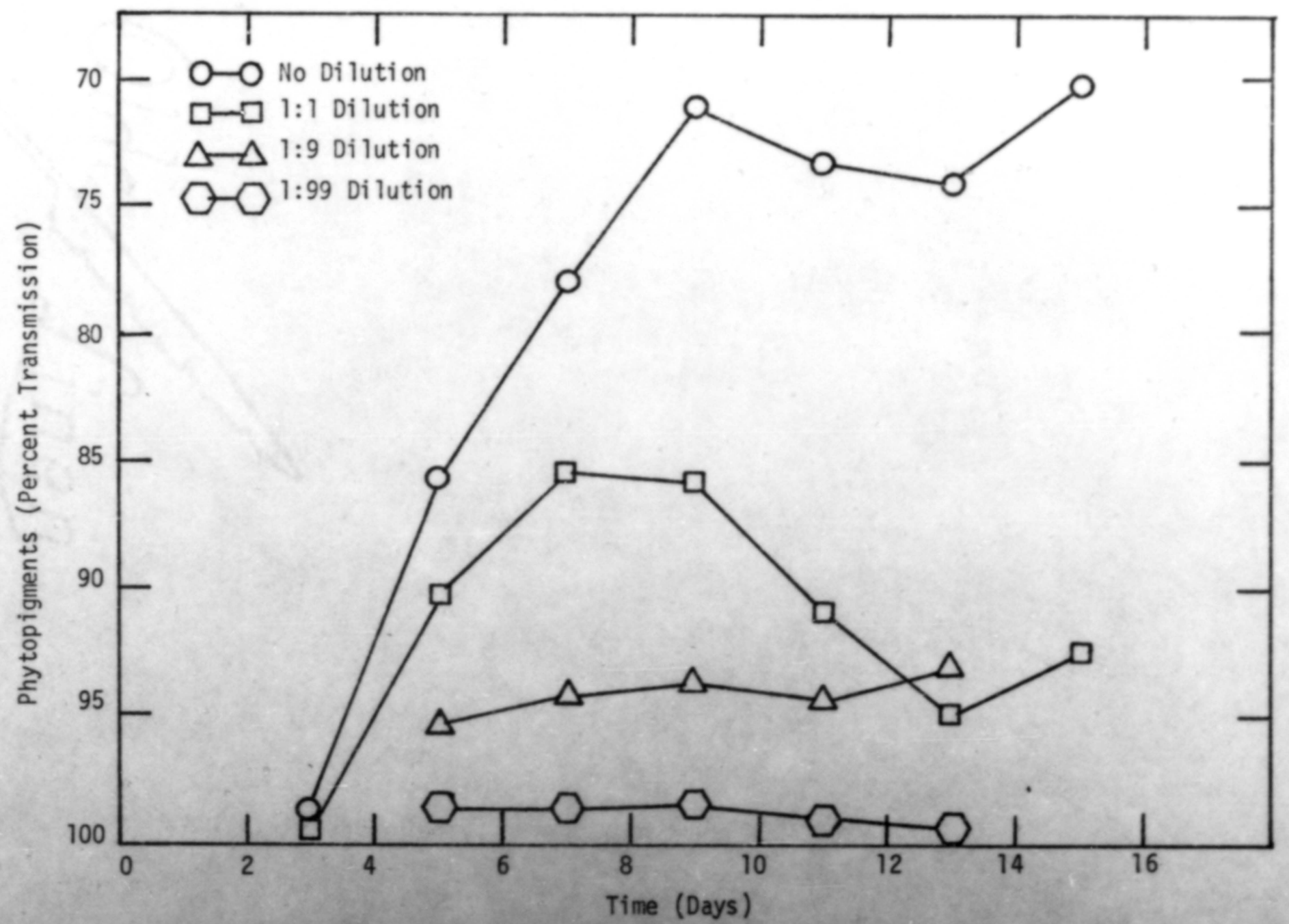

Figure 1. Phytopigment variation versus time for different dilutions of final effluent utilizing alum to remove phosphorus. 


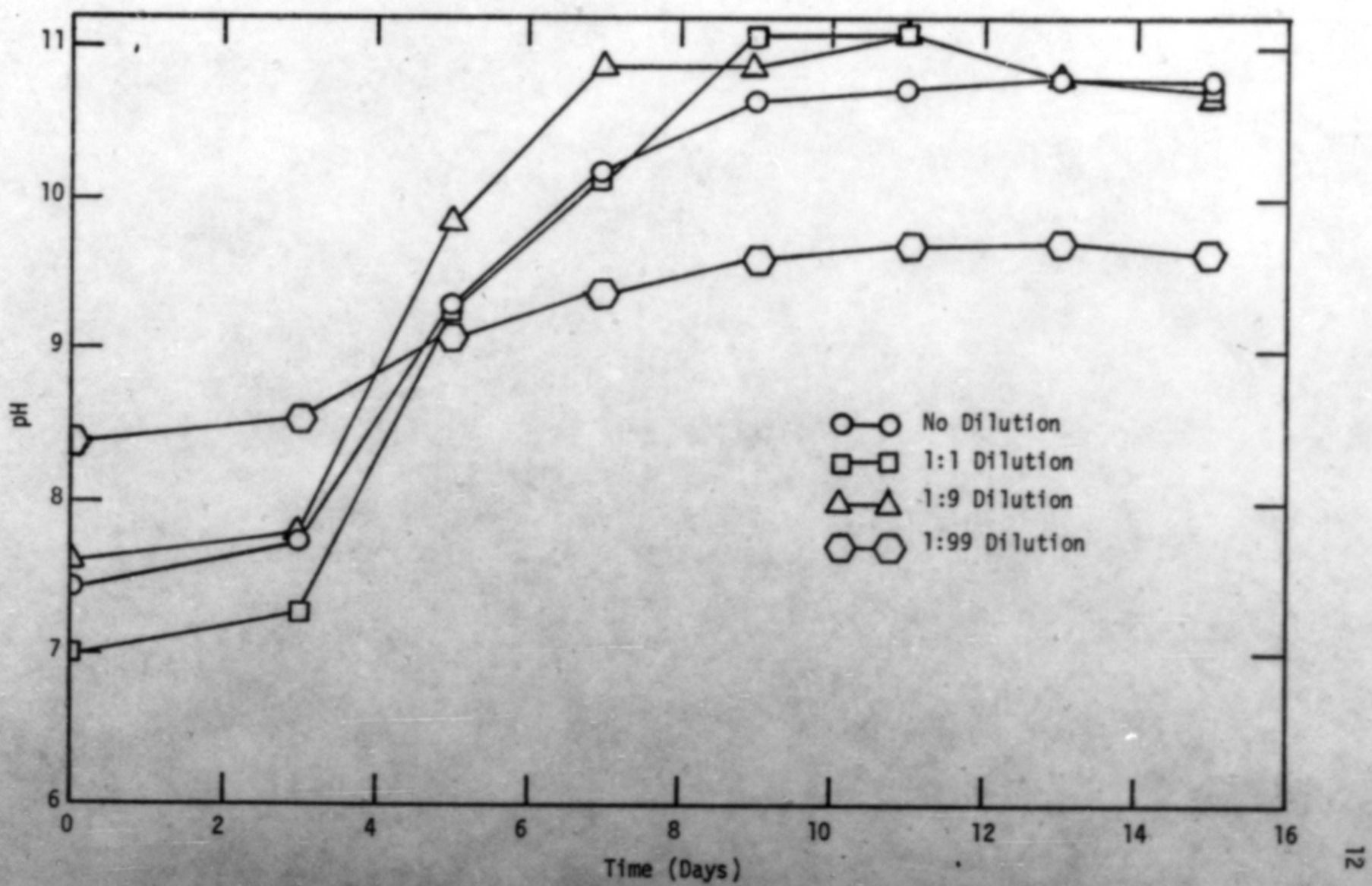

Figure 2. Variation in pH versus time for different difutions of final effluent utilizing alum to remove phosphorus. 


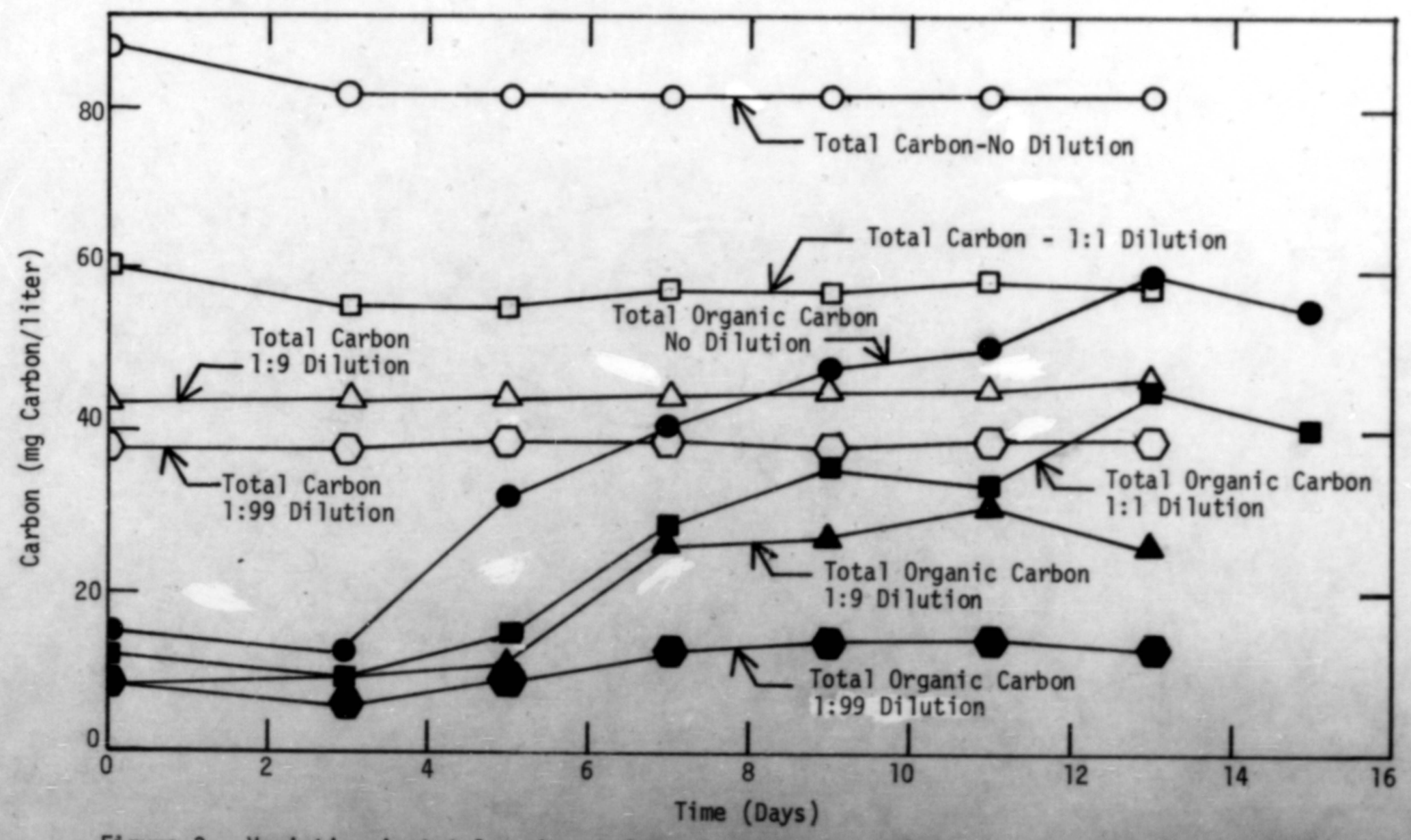

Figure 3. Variation in total carbon and total organic carbon versus time for different dilutions of final effluent utilizing alum to remove phosphorus. 


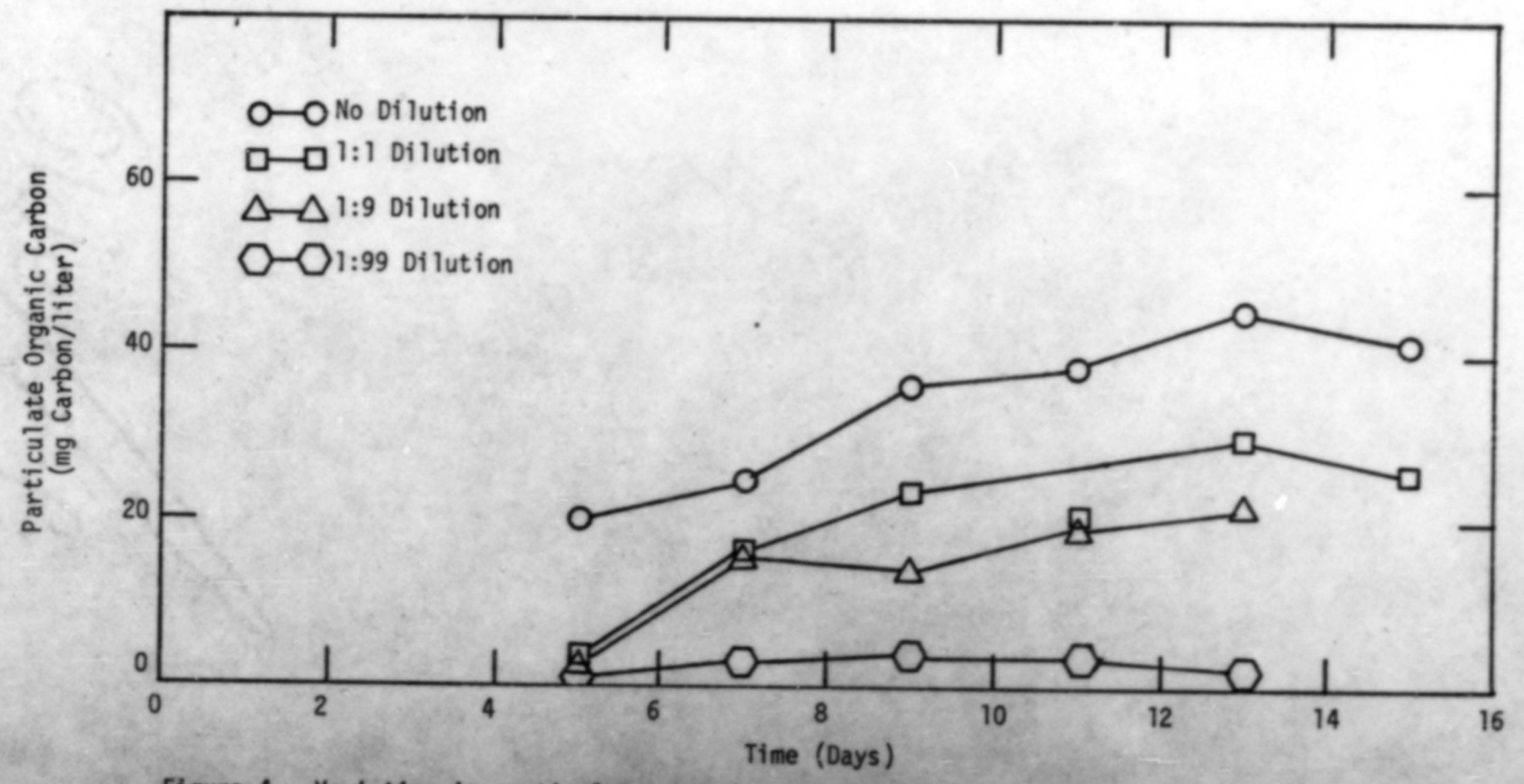

Figure 4. Variation in particulate organic carbon versus time for different dilutions of final effluent utilizing alum to remove phosphorus. 


$$
I C=T C-T O C X
$$

where

$$
\begin{aligned}
\mathrm{IC} & =\text { inorganic carbon in milligrams } \mathrm{C} / 1 \mathrm{iter} \\
\mathrm{TC} & =\text { total carbon in } \mathrm{mg} \mathrm{C} / 1 \mathrm{iter} \\
\mathrm{TOCX} & =\text { total organic carbon in mg } \mathrm{C} / 1 \mathrm{iter}
\end{aligned}
$$

A modification of Buch's (9) equation yields bicarbonate-carbonate alkalinity.

$$
\mathrm{a}=\Sigma \mathrm{CO}_{2} /[\theta]
$$

where

$$
\Sigma \mathrm{CO}_{2}=\begin{aligned}
& \text { total inorganic carbon in millimoles as } \\
& \text { determined from Equation } 1 .
\end{aligned}
$$

and

$$
\theta=\left[\frac{H^{2} / K_{1}+H+K_{2}}{H+2 K_{2}}\right]
$$

where

$$
\begin{aligned}
& H=\begin{array}{l}
\text { hydrogen } \text { ion concentration as measured } \\
\text { by the } \mathrm{pH} \text { meter }
\end{array} \\
& \mathrm{K}_{1}=\text { first dissociation constant of carbonic acid } \\
& \mathrm{K}_{2}=\text { second dissociation constant of carbonic acid } \\
& \mathrm{a}=\text { bicarbonate-carbonate alkalinity in milli- } \\
& \text { equivalents }
\end{aligned}
$$

The dissociation constants of carbonic acid are temperature dependent and this temperature dependence was accounted for in all calculations. 
From Equations 1 and 2 bicarbonate-carbonate alkalinity is equal to:

$$
a=[(T C-T O C X) / 12] /[\theta]
$$

Study of the calculated bicarbonate-carbonate alkalinity plotted against time as shown in Figures $5,6,7$ and 8 show an initial increase in bicarbonate-carbonate alkalinity followed by a decrease in bicarbonate-carbonate alkalinity in flasks which contain significant quantities of dissolved organic carbon from the final effluent. This initial increase in bicarbonate-carbonate alkalinity suggests that bacteria degraded some of the dissolved organic carbon from the final effluent to carbon dioxide since the total carbon concentration in each flask remained constant. The subsequent decrease in bicarbonatecarbonate alkalinity is attributable to algae fixing carbon from the bicarbonate-carbonate alkalinity system.

\section{Carbon Fixed Calculations. While particulate organic carbon} measurements are directly available from the data, the organic carbon fixed can be calculated from bicarbonate-carbonate alkalinity, total carbon and total organic carbon measurements. This calculation takes into account both the carbon availability to the algae from the initial bicarbonate-carbonate alkalinity, and the carbon supplied to the algae from bacterial degradation of the dissolved organic carbon.

From the initial increase in the bicarbonate-carbonate alkalinity the additional inorganic carbon added to the system from the degraded organic carbon can be estimated: 


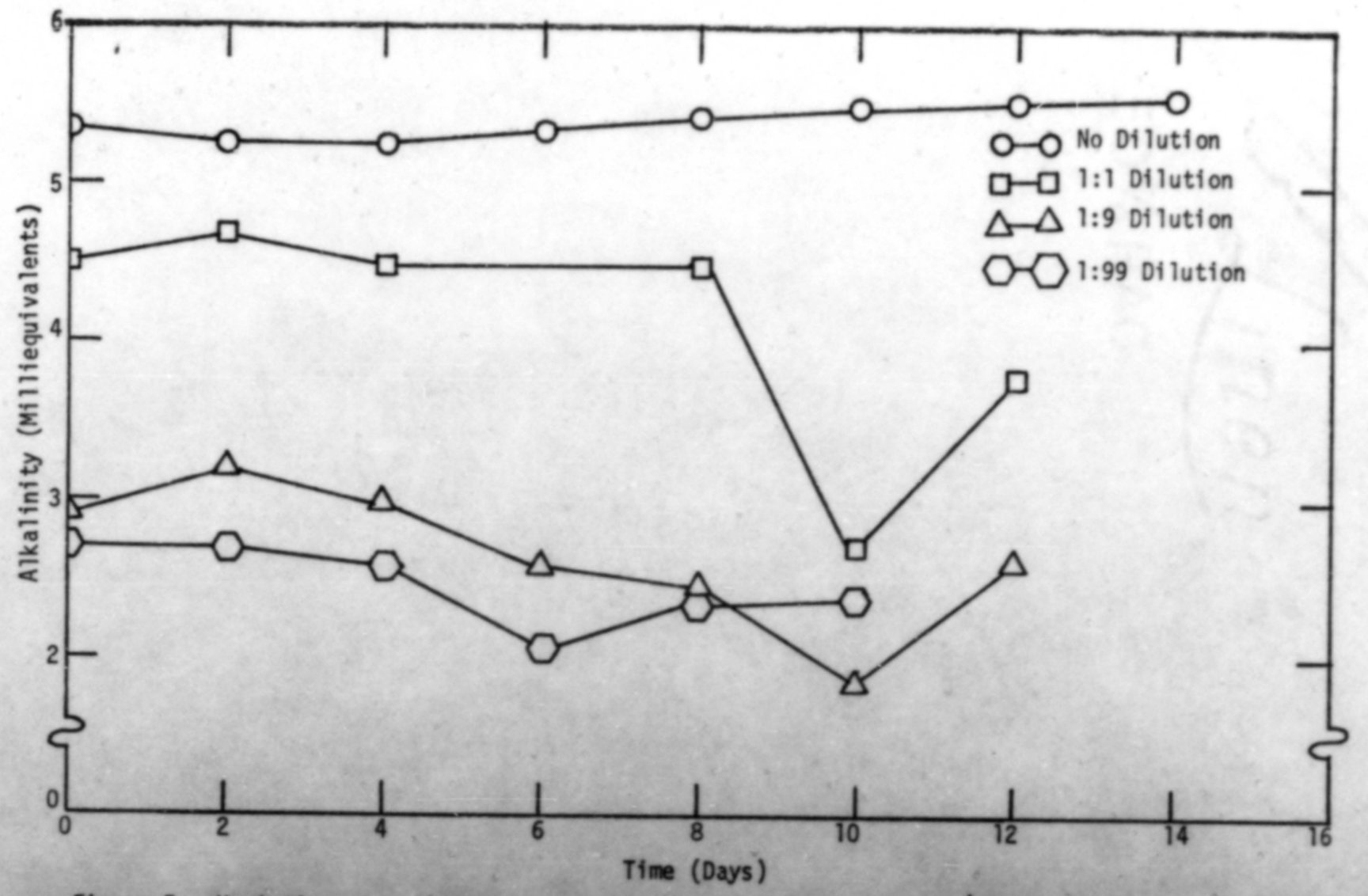

Figure 5. Variations in alkalinity versus time for different dilutions of final effluent with no phosphorus removal. 


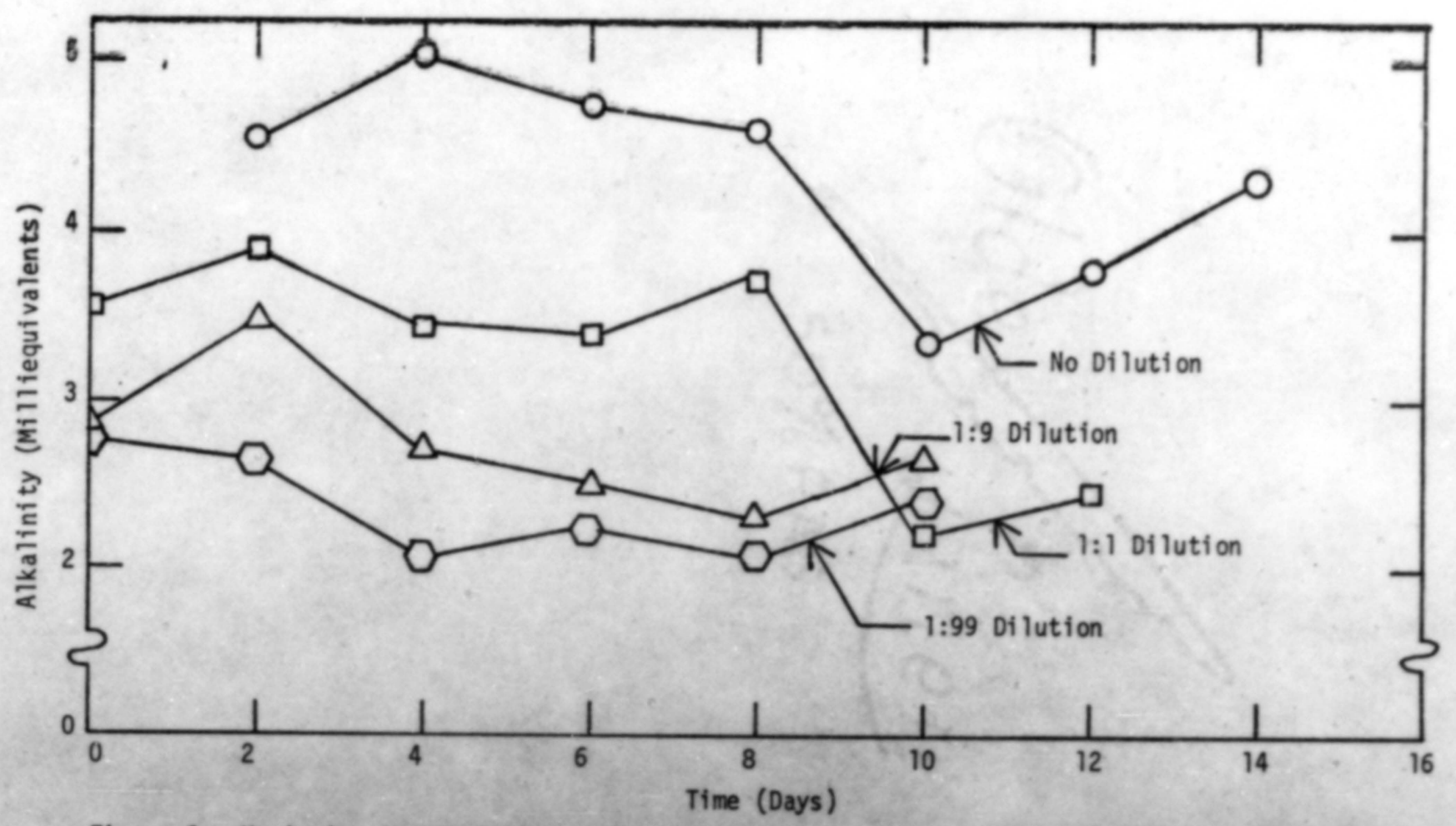

Figure 6. Variation in alkalinity versus time for different dilutions of final effluent utilizing alum for phos phorus removal. 


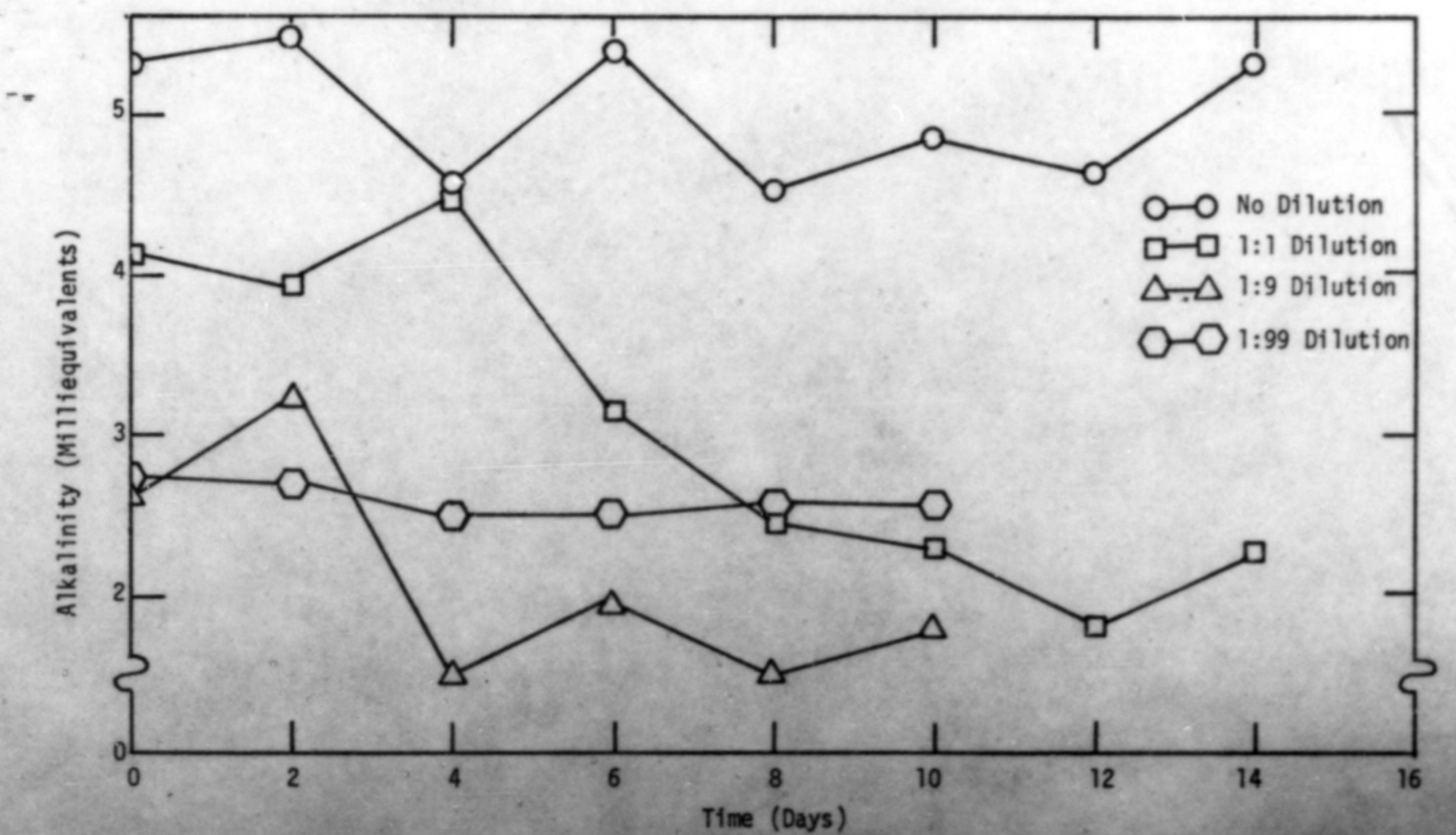

Figure 7. Variation in alkalinity versus time for different dilutions of final effluent utilizing iron for phosphorus removal. 


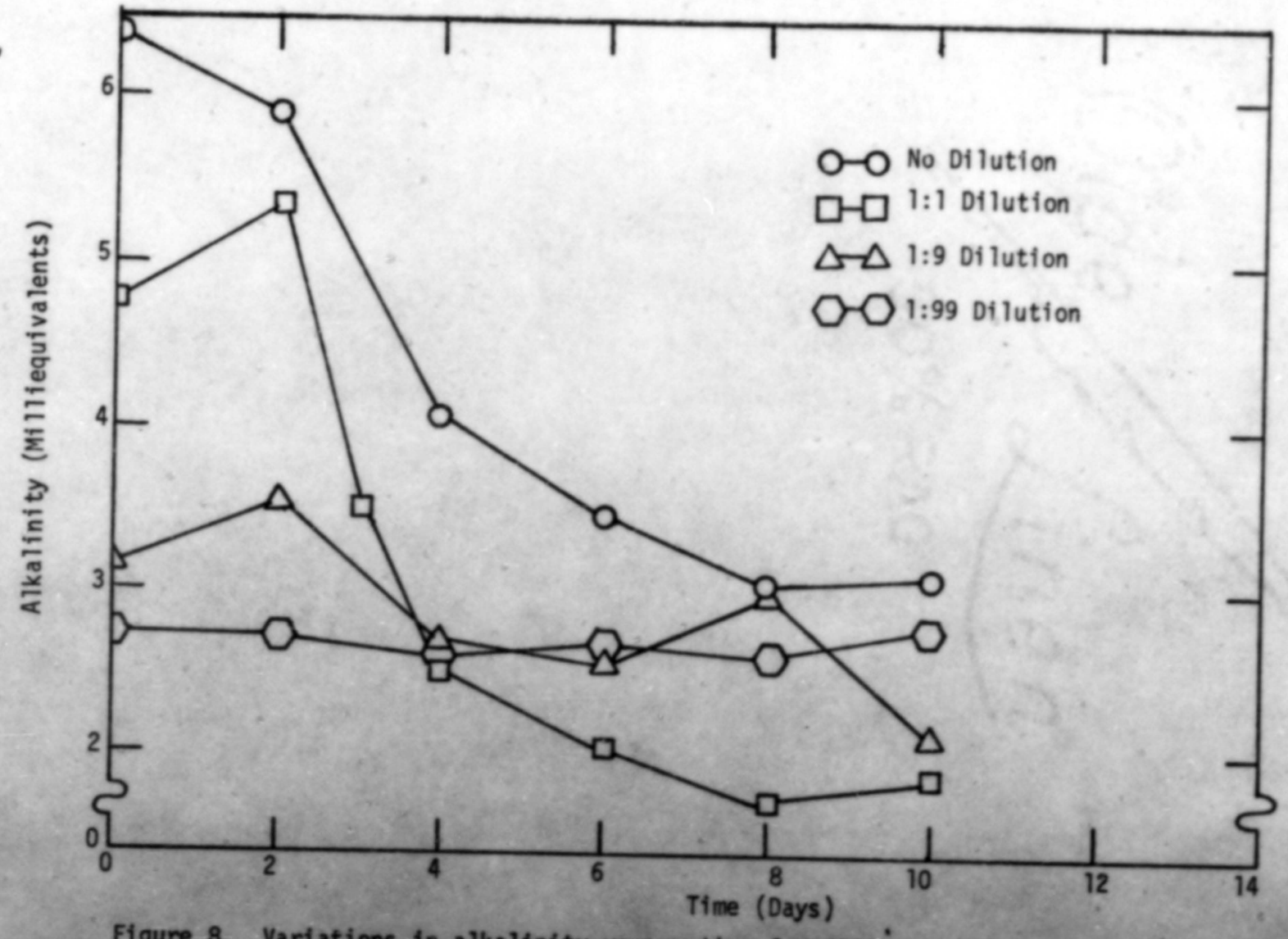

Figure 8. Variations in alkalinity versus time for different dilutions of final
effluent utilizing lime for phosphorus removal. 


$$
\begin{aligned}
& I C A=12\left(\left[\frac{(T C-T O C X) / 12}{\left[\theta_{X}\right]}\right]_{\text {MAX }}-\left[\frac{(T C-T O C 1) / 12}{\left[\theta_{1}\right]}\right]\right) \\
& I C A=\left[\frac{(T C-T O C X)}{\left[\theta_{X}\right]}\right]_{\text {MAX }}-\left[\frac{(T C-T O C 1)}{\left[\theta_{1}\right]}\right]
\end{aligned}
$$

where

$$
\begin{aligned}
& \text { ICA }=\begin{array}{l}
\text { inorganic carbon added due to } \\
\text { degradated organic in mg C/liter }
\end{array} \\
& \text { TOC } 1=\text { initial total organic carbon in }_{\text {mg } C / 1 i \text { ter }} \\
& {\left[\frac{\mathrm{TC}-\mathrm{TOCX}}{\left[\theta_{\mathrm{X}}\right]}\right]_{\text {MAX }}=\text { maximum alkalinity in } \mathrm{mg} \mathrm{C} / 1 \mathrm{iter}} \\
& {\left[\frac{\mathrm{TC}-\mathrm{TOC}]}{\left[\theta_{1}\right]}\right]=\text { initial alkalinity in } \mathrm{mg} \mathrm{C} / 1 \mathrm{iter}}
\end{aligned}
$$

The non-biodegradable dissolved organic carbon added with the final filtered effluent can be determined by subtracting the degraded portion of the organic carbon added to the bicarbonate-carbonate alkalinity from the initial total organic carbon.

$$
\mathrm{NBOC}=\mathrm{TOC1}-\mathrm{ICA}
$$

where

$$
\begin{aligned}
& \text { NBOC }= \text { non-biodegradable organic carbon } \\
& \text { in mg C/liter }
\end{aligned}
$$


These values are shown in Table 1.

The maximum carbon available to the algae then was equal to the sum of initial inorganic carbon and the inorganic carbon added to the system by bacterial degradation of organic carbon in the effluent. Summing Equations 1 and 5 yields:

$$
\mathrm{TC}(\mathrm{A})=\mathrm{TC}-\mathrm{TOC} 1+\mathrm{ICA}
$$

where

$$
\begin{aligned}
& \mathrm{TC}(\mathrm{A})= \text { total carbon available to the algae } \\
& \text { in } \mathrm{mg} C / \mathrm{liter}
\end{aligned}
$$

To determine the initial calculated carbon fixed by the algae, the inorganic carbon remaining at the point of maximum alkalinity was subtracted from the total carbon available. The initial calculated carbon fixed then was equal to:

$$
C_{F 1}=T C(A)-(T C-T O C X)_{\text {MAX }}
$$

where

$$
\begin{aligned}
C_{F 1}= & \begin{array}{l}
\text { initial calculated carbon } \\
\text { fixed in mg } C / l i t e r
\end{array} \\
(T C-T O C X)_{M A X}= & \begin{array}{l}
\text { inorganic carbon at maximum } \\
\text { alkalinity }
\end{array}
\end{aligned}
$$

Because all of the carbon available to the algae from the degraded organic carbon in the effluent was accounted for in Equation 8, the additional carbon fixed by the algae is equal to the reduction in organic carbon. The total calculated carbon fixed at each point in 
Table 1. Non-biodegradable organic carbon in each algae culture.

\begin{tabular}{|c|c|c|c|}
\hline $\begin{array}{l}\text { Flask } \\
\text { No. }\end{array}$ & Treatment & $\begin{array}{l}\text { Dilution } \\
\text { With Media }\end{array}$ & $\begin{array}{l}\text { Non-Biodegrad- } \\
\text { able Organic } \\
\text { Carbon } \\
\text { mg/1 }\end{array}$ \\
\hline A & None & None & 14.7 \\
\hline B & None & $1: 9$ & 9.9 \\
\hline$C$ & None & $1: 9$ & 5.3 \\
\hline$D$ & None & $1: 99$ & 7.3 \\
\hline Al & Alum & None & 6.2 \\
\hline B1 & Alum & $1: 1$ & 5.6 \\
\hline $\mathrm{Cl}$ & Alum & $1: 9$ & 0.5 \\
\hline DI & Alum & $1: 99$ & 0.0 \\
\hline A2 & Iron & None & 11.7 \\
\hline B2 & Iron & $1: 1$ & 5.6 \\
\hline $\mathrm{C} 2$ & Iron & $1: 9$ & 1.4 \\
\hline $\mathrm{D} 2$ & Iron & $1: 99$ & 6.0 \\
\hline A3 & Lime & None & 13.3 \\
\hline B3 & Lime & $1: 1$ & 5.5 \\
\hline $\mathrm{C} 3$ & Lime & $1: 9$ & 3.5 \\
\hline D3 & Lime & $1: 99$ & 6.6 \\
\hline
\end{tabular}


time was equal to the sum of the initial calculated carbon fixed and the total decrease in inorganic carbon to that point in time. Carbon fixed was then equal to:

$$
C_{F}=C_{F 1}+[(T C-T O C 1)-(T C-T O C X)]
$$

where

$$
C_{F}=\text { calculated carbon fixed in mg } \mathrm{C} / 1 \text { iter }
$$

Comparison of maximum calculated carbon fixed for each flask to maximum measured particulate organic carbon is shown in Figure 9. This graph seems to suggest that there is a nearly constant difference in carbon fixed between the calculated and particulate (measured) forms of organic carbon regardless of the total organic carbon in the flask. Hellebust (10) stated that under high light intensities heal thy algae excreted $17-38 \%$ of their photoassimilated carbon. Table two lists the ratio of maximum measured dissolved organic carbon to maximum measured total organic carbon for each of the flasks. Tnis ratio is an estimate of organic carbon leaked from the algae. It should be noted that as the total organic carbon values become smaller the ratio increases, suggesting increased carbon leakage at lower carbon fixed values. This would explain the apparent anomaly shown in Figure 9. The calculated carbon fixed values include leaked organic material while measured particulate organic carbon values do not include leakage. An increase in the ratio at lower carbon fixed values and a low ratio at high carbon fixed values would indicate a relatively constant difference between calculated carbon fixed and 


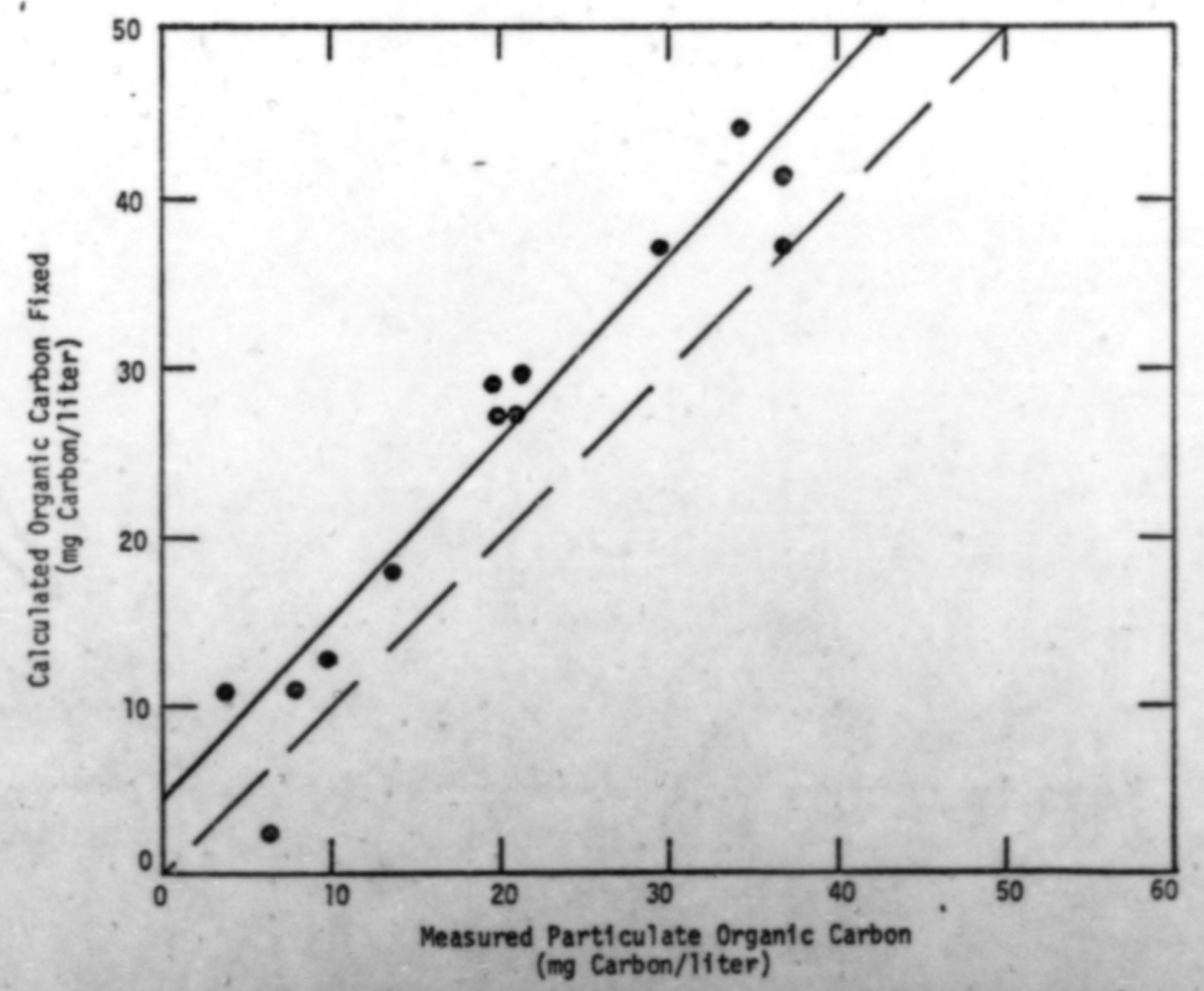

Figure 9. Comparison of calculated organic carbon fixed to measured particulate organic carbon. 
Table 2. Ratio of maximum measured dissolved organic carbon to maximum measured total organic carbon.

\begin{tabular}{|c|c|c|c|c|c|}
\hline $\begin{array}{l}\text { Flask } \\
\text { No. }\end{array}$ & $\begin{array}{c}\text { Phosphorus } \\
\text { Removal } \\
\text { Technique }\end{array}$ & $\begin{array}{l}\text { Dilution } \\
\text { W/Media }\end{array}$ & $\begin{array}{c}\text { Dissolved } \\
\text { Organic } \\
\text { Carbon }\end{array}$ & $\begin{array}{l}\text { Total } \\
\text { Organic } \\
\text { Carbon }\end{array}$ & $\frac{\text { Dis Org C }}{\text { Total Org C }}$ \\
\hline A & None & None & - & - & - \\
\hline B & None & $1: 1$ & 13.5 & 48.5 & 27.8 \\
\hline$C$ & None & $1: 9$ & 7.5 & 28.5 & 26.3 \\
\hline D & None & $1: 99$ & 8.0 & 19.0 & 42.1 \\
\hline Al & Alum & None & 14.0 & 59.0 & 23.8 \\
\hline B1 & Alum & $1: 1$ & 10.5 & 40.5 & 25.9 \\
\hline $\mathrm{Cl}$ & Alum & $1: 9$ & 8.5 & 25.5 & 33.3 \\
\hline D1 & Alum & $1: 99$ & 7.0 & 11.0 & 63.6 \\
\hline A2 & Iron & None & 14.0 & 50.0 & 28.0 \\
\hline B2 & Iron & $1: 1$ & 12.5 & 46.5 & 26.9 \\
\hline $\mathrm{C} 2$ & Iron & $1: 9$ & 10.5 & 26.5 & 39.7 \\
\hline $\mathrm{D} 2$ & Iron & $1: 99$ & 11.0 & 15.0 & 73.4 \\
\hline A3 & Lime & None & 15.0 & 68.0 & 22.1 \\
\hline B3 & Lime & $1: 1$ & 11.5 & 53.5 & 21.5 \\
\hline C3 & Lime & $1: 9$ & 8.5 & 23.5 & 36.2 \\
\hline D3 & Lime & $1: 99$ & 7.0 & 12.0 & 58.3 \\
\hline
\end{tabular}


measured particulate carbon values. This was in fact due to differential rates of carbon leakage from algae grown under differing conditions of carbon and phosphorus availability.

\section{Phosphorus Calculations}

The effectiveness of the three methods of phosphorus removal utilized in this investigation are shown in Table 3. Doses of the phosphorus removal agents were deliberately varied to give the wide range of phosphorus concentrations needed for this investigation. Better removal could have been obtained with higher doses of the chemicals.

Phosphorus uptake by the algae was computed by two different methods. The first method was subtraction of final total dissolved phosphorus from the initial total phosphorus. This yielded the apparent phosphorus uptake. The second method was computation of the change in orthophosphorus by subtracting the final dissolved orthophosphate from the initial total orthophosphate. Figure 10 is a comparison of these two methods of calculation. This figure clearly indicates a one to one ratio between the two methods. This suggests that only orthophosphate is fixed by algae and that a significant portion of the total phosphorus is not available to the algae. Because it does not differ significantly from the apparent phosphorus uptake, orthophosphorus uptake values were used as the measurement of the phosphorus used by the algae for the remainder of this study. 
Table 3. Phosphorus removal and phosphorus removal efficiencies.

\begin{tabular}{ccccc}
\hline & $\begin{array}{c}\text { Total } \\
\text { Type of } \\
\text { Removal }\end{array}$ & $\begin{array}{c}\text { Concentration } \\
\mathrm{mg} / 1\end{array}$ & $\begin{array}{c}\text { Ortho- } \\
\text { Phosphorus } \\
\text { Concentration } \\
\mathrm{mg} / 1\end{array}$ & $\begin{array}{c}\% \\
\text { Removal }\end{array}$ \\
\hline None & 6.86 & 0 & 6.52 & 0 \\
Alum & 1.00 & 85.4 & .59 & 90.6 \\
Iron & 2.43 & 64.4 & 2.38 & 63.5 \\
Lime & 1.85 & 73.1 & 1.49 & 77.2 \\
\hline
\end{tabular}




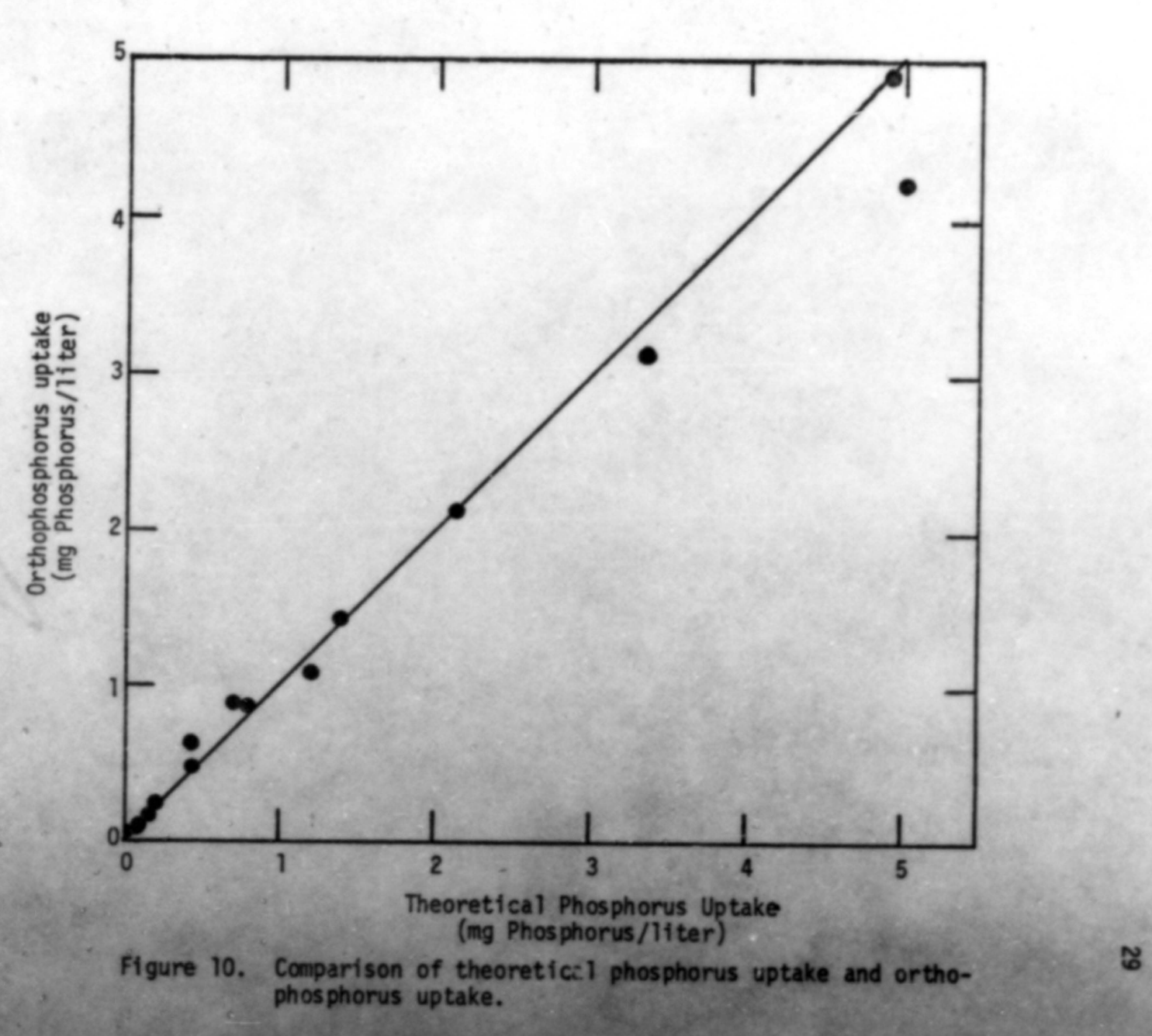




\section{Carbon to Phosphorus Ratios}

One of the best methods for fllustrating algal cell carbon and phosphorus relationships is the carbon to phosphorus ratio. This ratio is derived on an atomic weight basis and is the ratio of the number of carbon atoms to the number of phosphorus atoms in an algal ce11. Such ratios for algae have long been a matter of contention (1) (2). It is generally accepted that algae are capable of storing phosphorus (3). In waters with high phosphorus concentration the $C: P$ ratio of the algae could be expected to be low while algae in water with lower phosphorus concentrations, the $C: P$ ratio should be higher.

From the previous calculations and measured data two types of carbon to phosphorus ratios can be computed for the algae used in this study. The first ratio is that of calculated carbon fixed to orthophosphorus uptake $\left(C_{F}: P\right)$, and the second is the ratio of measured particulate organic carbon to orthophosphorus uptake $\left(C_{P}: P\right)$. Table 4 lists both ratios for all sixteen flasks. These ratios were based on maximum values of calculated carbon fixed $\left(C_{F}\right)$, measured particulate organic carbon $\left(C_{p}\right)$, and orthophosphorus uptake $(P)$ for each flask. Consequently the ratios are for the algae in each flask at the point of peak algal production.

From Table 4 it can be seen that there is considerable variation in the $C: P$ ratios, in fact they vary from $C_{1.3}: P_{1}$ to $C_{2030}$. Because of the wide range of carbon and phosphorus concentrations in the sixteen flasks, the variation of $C: P$ ratios suggests that the ratios are 
Table 4. Calculated carbon fixed to orthophosphorus uptake ratios and measured particulate organic carbon to orthophosphorus uptake ratios.

\begin{tabular}{|c|c|c|c|c|}
\hline Number & $\begin{array}{l}\text { Phosphorus } \\
\text { Removal } \\
\text { Method }\end{array}$ & $\begin{array}{l}\text { Dilution } \\
\text { W/Media }\end{array}$ & $C_{F}: P$ & $C_{P}: P$ \\
\hline A & None & None & 1.3 & 3.3 \\
\hline B & None & 1:1 & 34.0 & 30.2 \\
\hline$C$ & None & $1: 9$ & 114.0 & 87.4 \\
\hline$D$ & None & $1: 99$ & 844.0 & 645.0 \\
\hline Al & Alum & None & 155.0 & 133.0 \\
\hline B1 & Alum & 1:1 & 205.0 & 164.0 \\
\hline $\mathrm{Cl}$ & Alum & $1: 9$ & 1140.0 & 815.0 \\
\hline DI & Alum & $1: 99$ & 2030.0 & 680.0 \\
\hline $\mathrm{A} 2$ & Iron & None & 45.0 & 45.0 \\
\hline B2 & Iron & $1: 1$ & 105.0 & 82.0 \\
\hline $\mathrm{C} 2$ & Iron & $1: 9$ & 319.0 & 216.0 \\
\hline $\mathrm{D} 2$ & Iron & $1: 99$ & 1017.0 & 766.0 \\
\hline A3 & Lime & None & 98.5 & 69.0 \\
\hline B3 & Lime & $1: 1$ & 152.0 & 129.0 \\
\hline $\mathrm{C} 3$ & Lime & $1: 9$ & 474.0 & 344.0 \\
\hline D3 & Lime & $1: 99$ & 918.0 & 658.0 \\
\hline
\end{tabular}


dependent upon the relative availability of carbon and phosphorus to the algae.

It has been stated previously that the computed carbon fixed values include the total carbon fixed by the algae including carbon loss due to organic carbon leakage from the algal cells. On the other hand, measured particulate organic carbon is a measurement of only that carbon which is contained within the cell at the moment of measurement. Because the calculated carbon fixed value is the better measurement of total organic carbon production by the algae, the calculated carbon fixed to orthophosphorus uptake ratio $\left(C_{F}: P\right)$ is probably the best ratio for determining algal production potential. However, calculated carbon fixed values are not normally available in the field. Measured particulate organic carbon values can easily be determined in the laboratory from one sample gathered in the field. Therefore the measured particulate organic carbon to orthophosphorus uptake ratio $\left(C_{P}: P\right)$ is more applicable to normal field work. Both types of $C: P$ ratios were utilized in this study.

Optimum Carbon to Phosphorus Ratio. Data revealed that algae in some flasks developed phosphorus limits while others developed carbon limits. That is, algal productivity was limited due to the nonavailability of either phosphorus or carbon depending on the initial concentration of these two elements. A C:P ratio could be calculated for all flasks, and there should have been a $C: P$ ratio at which the carbon limit shifted to a phosphorus limit. This C:P ratio would be the ratio of the optimum blend of carbon-to phosphorus for the algae used in this study. 
Figures 11 and 12 indicate a linear relation between the two types of algal carbon and phytopigment measurements. The difference in the two figures is again due to the inclusion of leaked organic material from the algal cells in the calculated organic carbon fixed value. Consequently total phytosynthetic activity is represented by the total carbon fixed by the algae.

Figure 13 shows a logarithmic relation between phytopigments and orthophosphorus uptake at orthophosphorus uptake values of less than $0.34 \mathrm{mg} P / 1$ iter. Above $0.34 \mathrm{mg} P / 1$ ter the relation is not consistent. Taken together, Figures 11,12 , and 13 reveal a direct relationship between carbon fixed and orthophosphorus uptake below phosphorus uptake values of $0.34 \mathrm{mg} P / 1 i$ ter. This relationship between carbon fixed and orthophosphorus uptake is logarithmic in nature. Because of the low range of orthophosphorus uptake concentrations involved in the relationship, the figures suggest a phosphorus limit below 0.34 mg $P / 1$ iter.

From Figure $130.34 \mathrm{mg} P / 1$ iter orthophosphorus results in a phytopigment percent transmission of .88 . The calculated carbon fixed for this value of the percent transmission as shown in Figure 11 is 27.0 $\mathrm{mg} \mathrm{C} / 1$ iter. The measured particulate carbon for this value of percent transmission is $21.5 \mathrm{mg} \mathrm{C} / 11$ ter as shown in Figure 12. These carbon and phosphorus values compute to a $\mathrm{C}_{\mathrm{F} 205}: \mathrm{P}_{1}$ ratio and a $\mathrm{C}_{\mathrm{P} 153}: \mathrm{P}$ ratio. At ratios greater than the above ratios, phosphorus is the limiting nutrient for the algae used in this study. Presumably, at ratios below the above ratios, carbon is the limiting nutrient. 


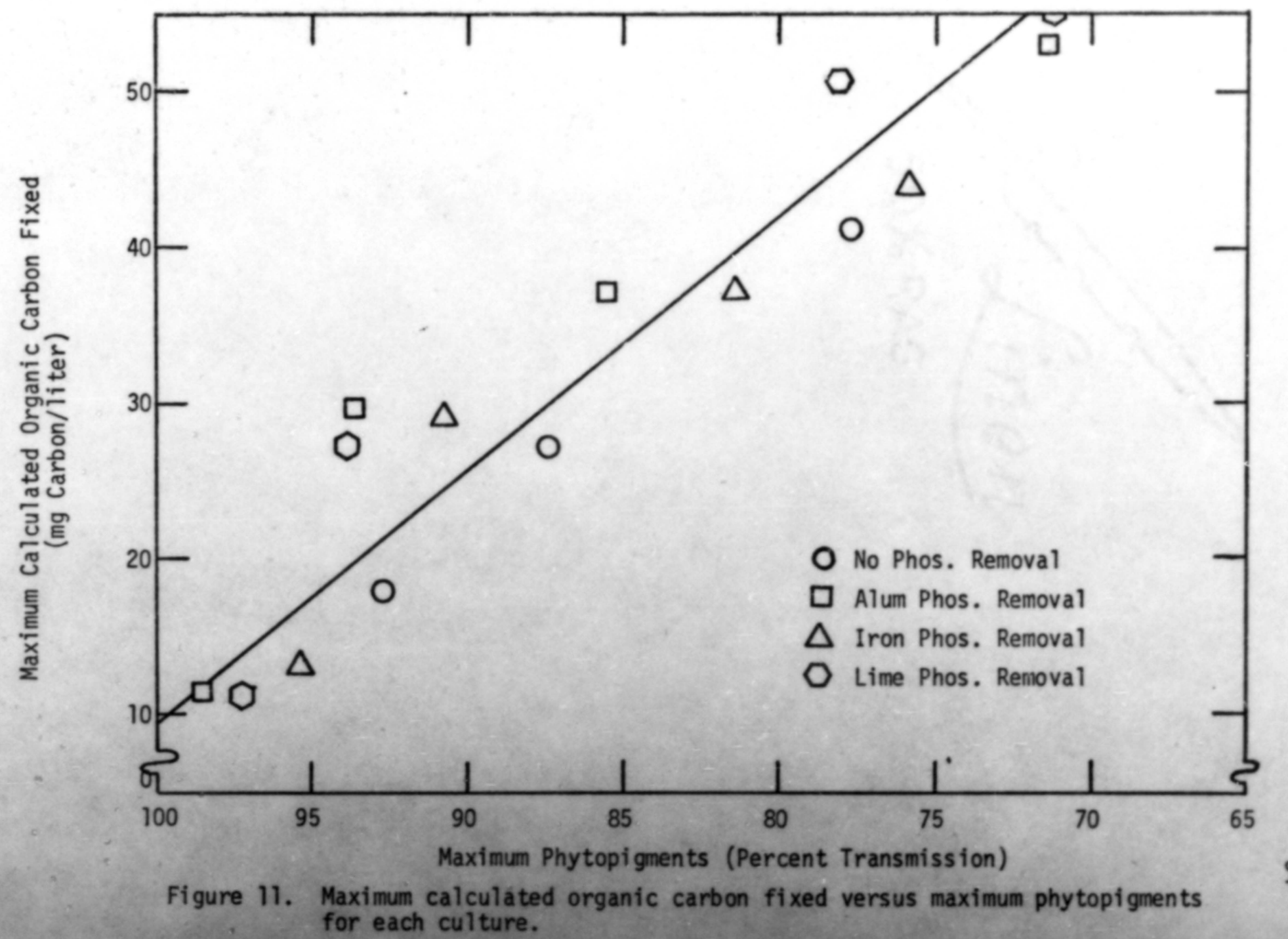




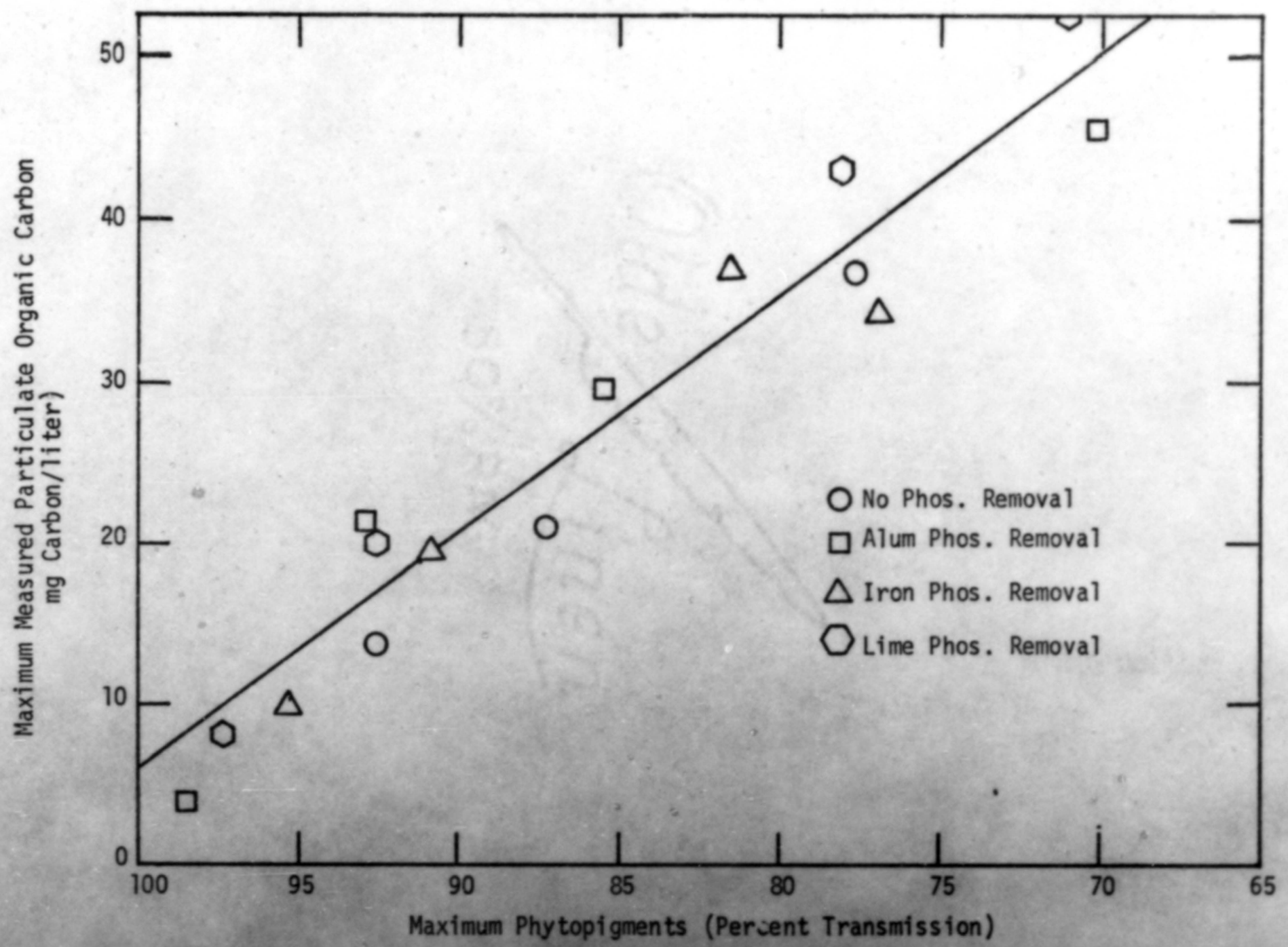

Figure 12. Maximum measured particulate organic carbon versus maximum phytopigments for each culture. 


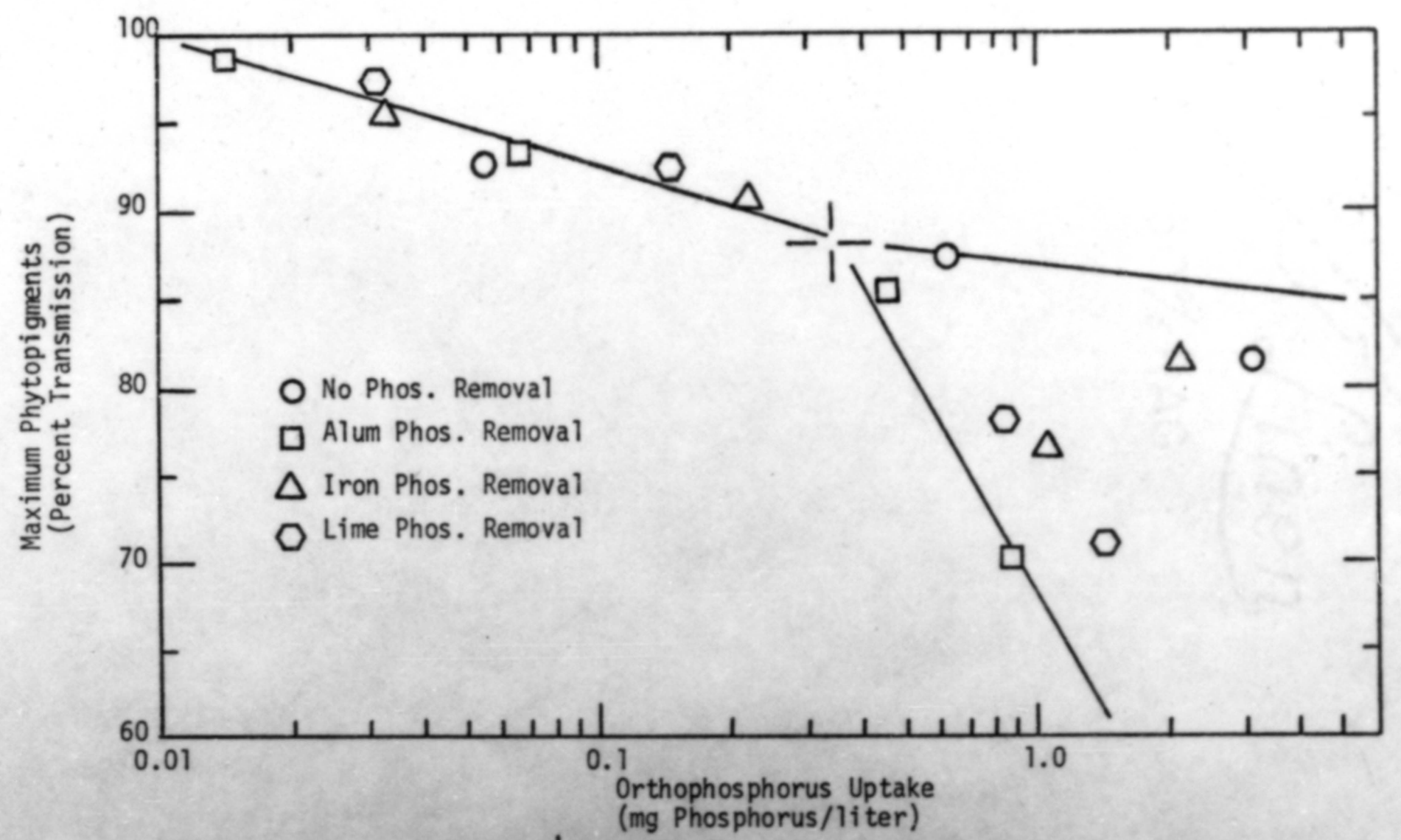

Figure 13. Orthophosphorus uptake versus maximum phytopigments for each culture. 
Figures 14 and 15 show a logarithmic relation between phytopigments and the two types of $C: P$ ratios. This relation holds for $C_{F}: P$ ratios greater than $C_{F 220}: P_{1}$ and $C_{P}: P$ ratios greater than $C_{P 180}: P_{1}$. At C:P ratios below these values the relation is not valid. High C:P ratios result from high algal carbon concentrations and low algal phosphorus concentrations. Therefore this logarithmic relation would seem to be in the region of phosphorus limitation.

Phytopigment determinations are a measure of photosynthetic activity. Consequently at all ratios above a $\mathrm{C}_{\mathrm{F} 220}: \mathrm{P}_{1}$ ratio and a $C_{P_{180}: P_{1}}$ ratios, photosynthetic activity appears to be 1 imited due to low phosphorus availability to the algae.

The relationships between orthophosphorus uptake and the $C_{F}: P$ ratio and the $C_{p}: P$ ratio are shown in Figures 16 and 17 respectively. They indicate two distinct logarithmic relationships for each type of ratio. It has already been established that an apparent phosphorus limit exists at high $C: P$ ratios. A low $C: P$ ratio implies that the algae contain large amounts of phosphorus and relatively small amounts of carbon. Since all other required nutrients except phosphorus were available in excess, carbon is therefore the only possible limiting nutrient. A carbon limit is present at low C:P ratios.

The two distinct relationships in each figure define the ranges of the carbon and phosphorus limitations for the algae used in this study. The point at which these relationships change is the point at which the limit shifts from carbon to phosphorus. The C:P ratios at which the relationships change are at a $C_{F}: P$ ratio of $C_{F 230}: P_{1}$ (Fig- 


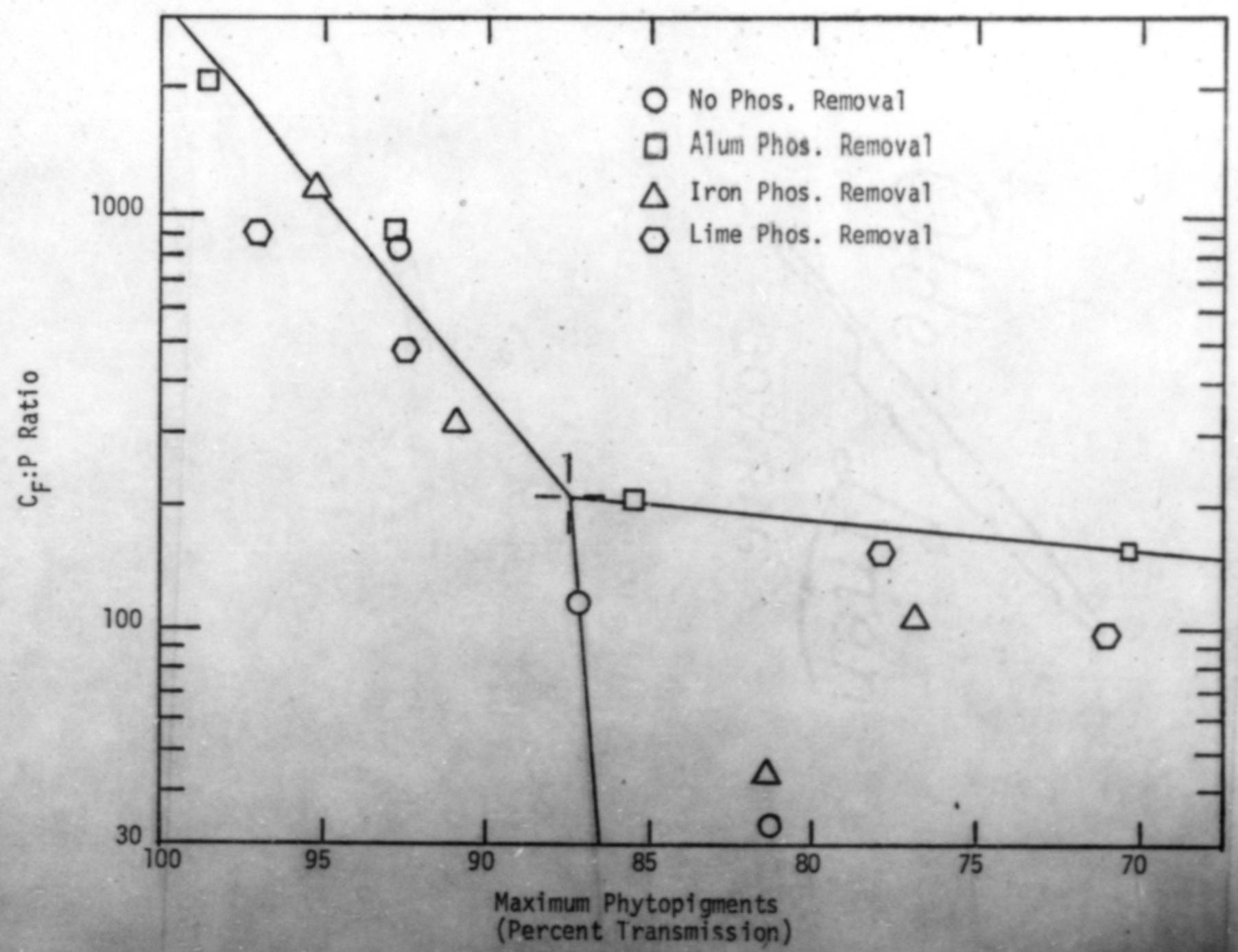

Figure 14. Maximum phytopigments versus the $C_{F}: P$ ratio for each algal culture. 


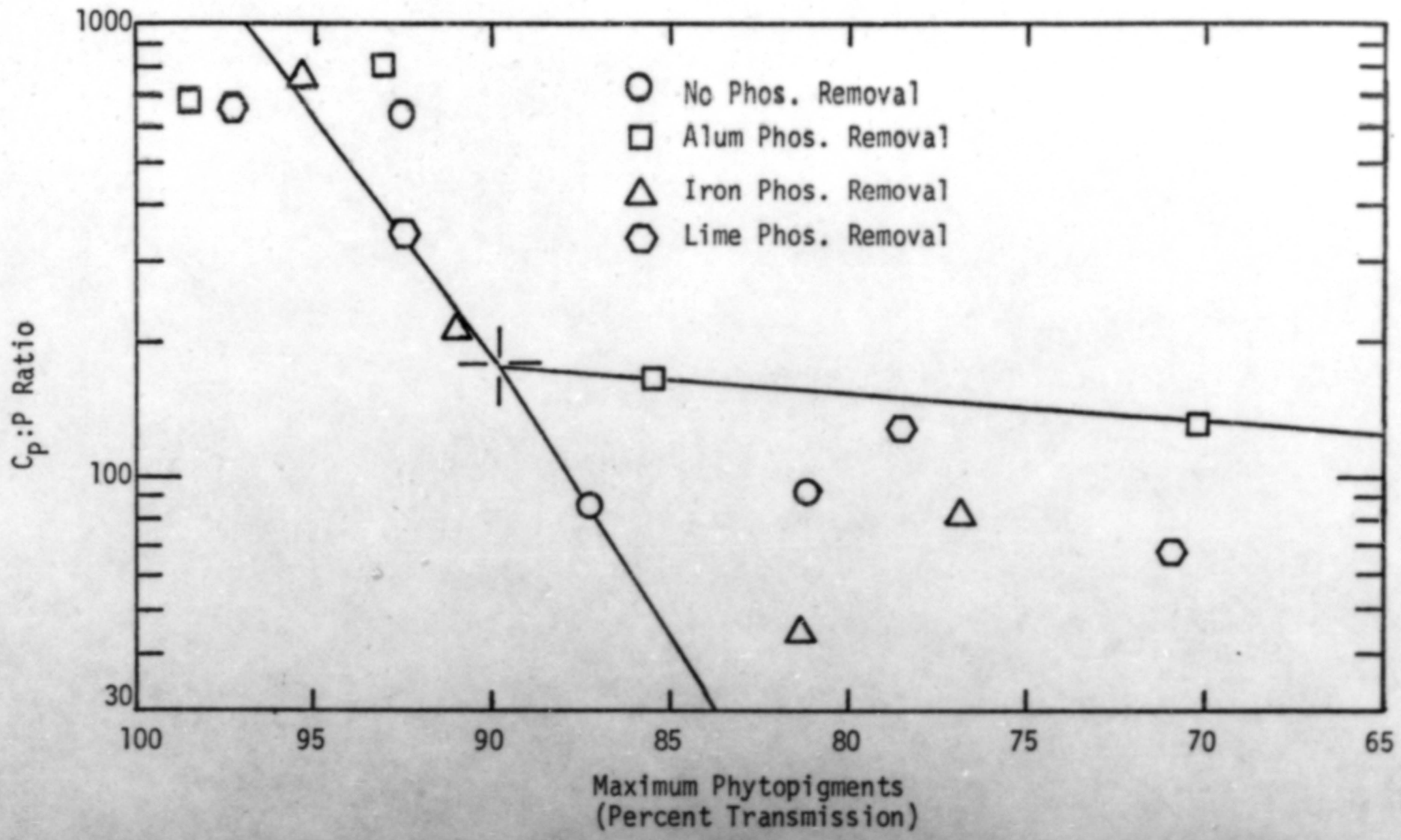

Figure 15. Maximum phytopigments versus the $C_{p}: P$ ratio for each algal culture. 


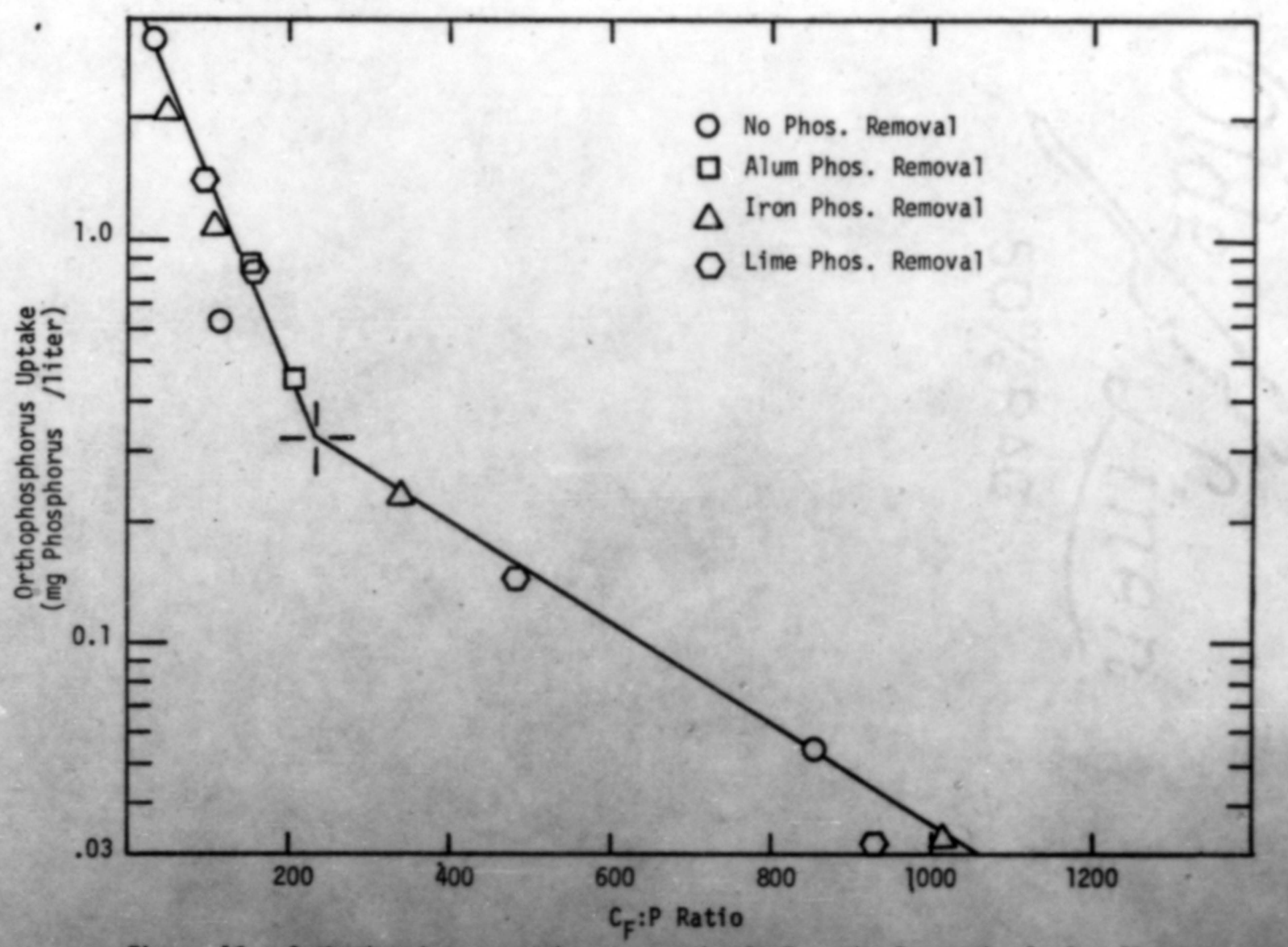

Figure 16. Orthophosphorus uptake versus the $C_{F}: P$ ratio for each algal culture. 


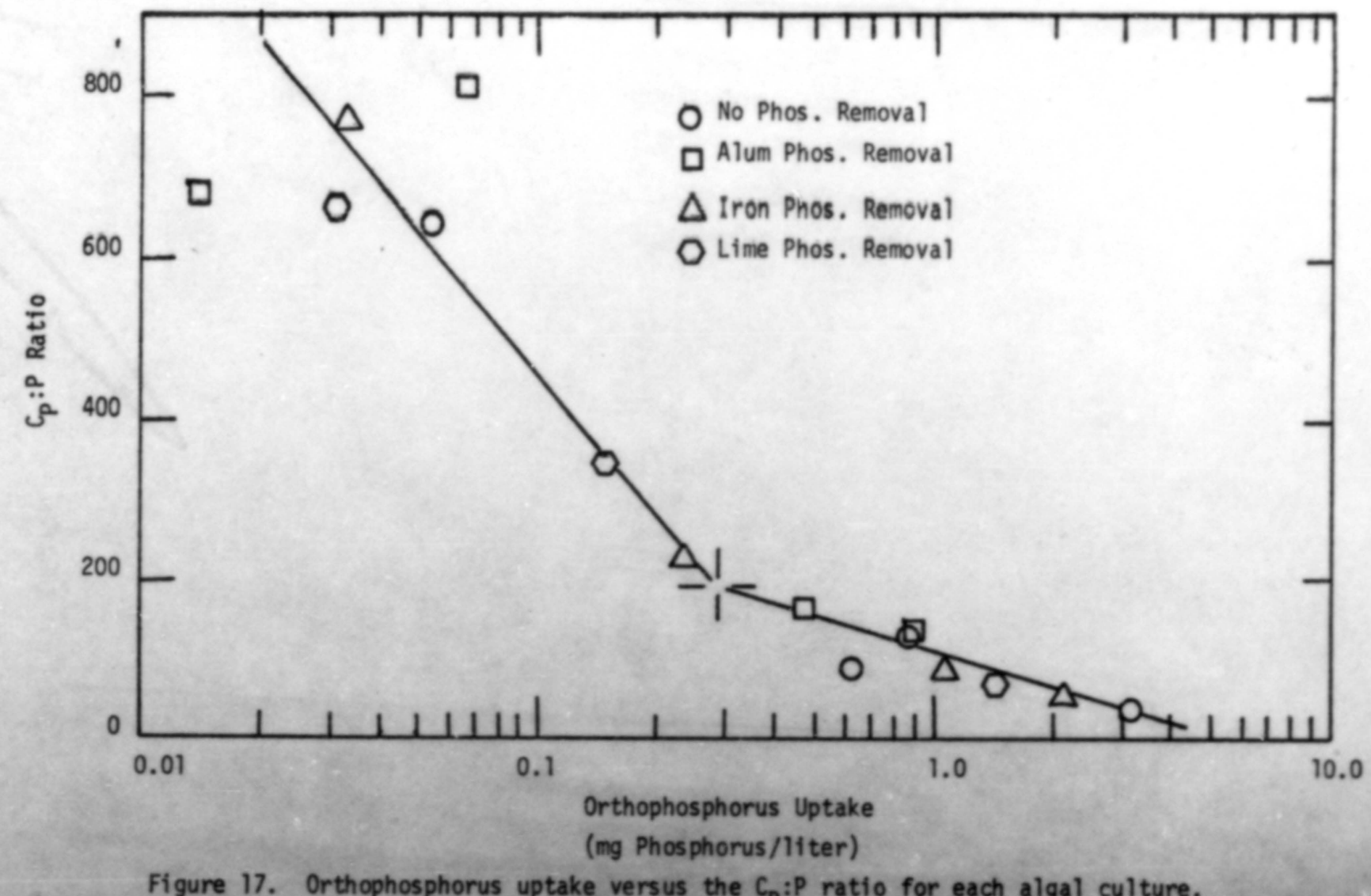

Figure 17. Orthophosphorus uptake versus the $C_{p}: P$ ratio for each algal culture. 
ure 16) and at a $C_{P}: P$ ratio of $C_{P_{190}}: P_{1}$ (Figure 17). These ratios represent the optimum blend of carbon and phosphorus for algal production.

Table 5 is a summary of the various C:P ratios determined from the preceding figures. These values are the ratios of optimum carbon and phosphorus blends. They average to an optimum $C_{F}: P$ ratio of $C_{F_{217}}: P_{1}$ and an optimum $C_{P}: P$ ratios of $C_{P_{177}}: P$. As previously mentioned, the calculated carbon fixed $\left(C_{F}\right)$ values were interpreted as a better measure of the total carbon uptake. Therefore, the $C_{F}: P$ ratios are a better indicator of actual algal demand for phosphorus and carbon. However, since some algal cells are harvested from natural systems, measurement considerations usually will require the use of the optimum $\mathrm{C}_{\mathrm{p}}: \mathrm{P}$ ratio.

It should be noted at this point in the investigation that these optimum C:P ratios were obtained from data collected in a laboratory under ideal conditions. The optimum carbon to phosphorus ratio for algae of different species than used in this study or living under field conditions may be different from the ones found here.

Calculation of carbon fixed on a weight basis show a difference between the calculated carbon fixed values $\left(C_{F}\right)$ and the measured particulate organic carbon $\left(C_{p}\right)$ of approximately $22 \%$. This suggests that even at the optimum ratio, under the conditions of this study, the algae leaked $22 \%$ of their photosynthate to the water. It also suggests that these algae, at the optimum balance of carbon and phosphorus availability are $78 \%$ efficient in converting primary photosynthate to algal biomass. 
Table 5. Summary of optimum C:P ratios.

\begin{tabular}{lcc}
\hline \multicolumn{1}{c}{ Source } & $C_{F}: P$ & $C_{P}: P$ \\
\hline $\begin{array}{l}\text { Calculated from Fig. } \\
11,12, \text { and } 13\end{array}$ & 205 & 163 \\
Figures 14 and 15 & 220 & 180 \\
Figures 16 and 17 & 230 & 190 \\
Average Value & 217 & 177 \\
\hline
\end{tabular}


Having established a $\mathrm{C}_{\mathrm{F} 217}: \mathrm{P}_{1}$ ratio as the optimum balance of carbon to phosphorus for algae, the phenomenon of organic carbon leakage from algal cells bears investigation. Figure 18 is a plot of orthophosphorus uptake versus the ratio of maximum measured dissolved organic carbon to maximum measured total organic carbon for each flask. This ratio is an indicator of the amount of organic material leaked from the cells. It should be remembered that the bicarbonatecarbonate alkalinity increases in most of the flasks. This indicates that most of the original dissolved organic carbon in the effluent had been degraded by bacterial action. From Figure 18, it can be seen that the maximum measured dissolved organic carbon to maximum measured total organic carbon ratio remains constant at about 26.5 percent to a phosphorus uptake value of $0.40 \mathrm{mg} P / 1$ ter. This compares favorably with the 22 percent difference between the calculated carbon fixed values and measured particulate organic carbon values attributed to algal cell leakage.

From Figure 16 a phosphorus uptake of $0.40 \mathrm{mg} P / 1$ ter results in a $C_{F 220}: P_{1}$ ratio which is approximately the ratio at which the carbon limit shifts to a phosphorus limit.

At lower values of orthophosphorus uptake in the phosphorus limit region, the measured dissolved organic carbon to measured total organic carbon ratio increases dramatically. According to Meyer and Anderson (11) a phosphorus deficiency in plants results in a decrease in synthesis of proteins with an accompanying accumulation of sugars. In the case of algae the sugars probably would be leaked through the semi-permeable 


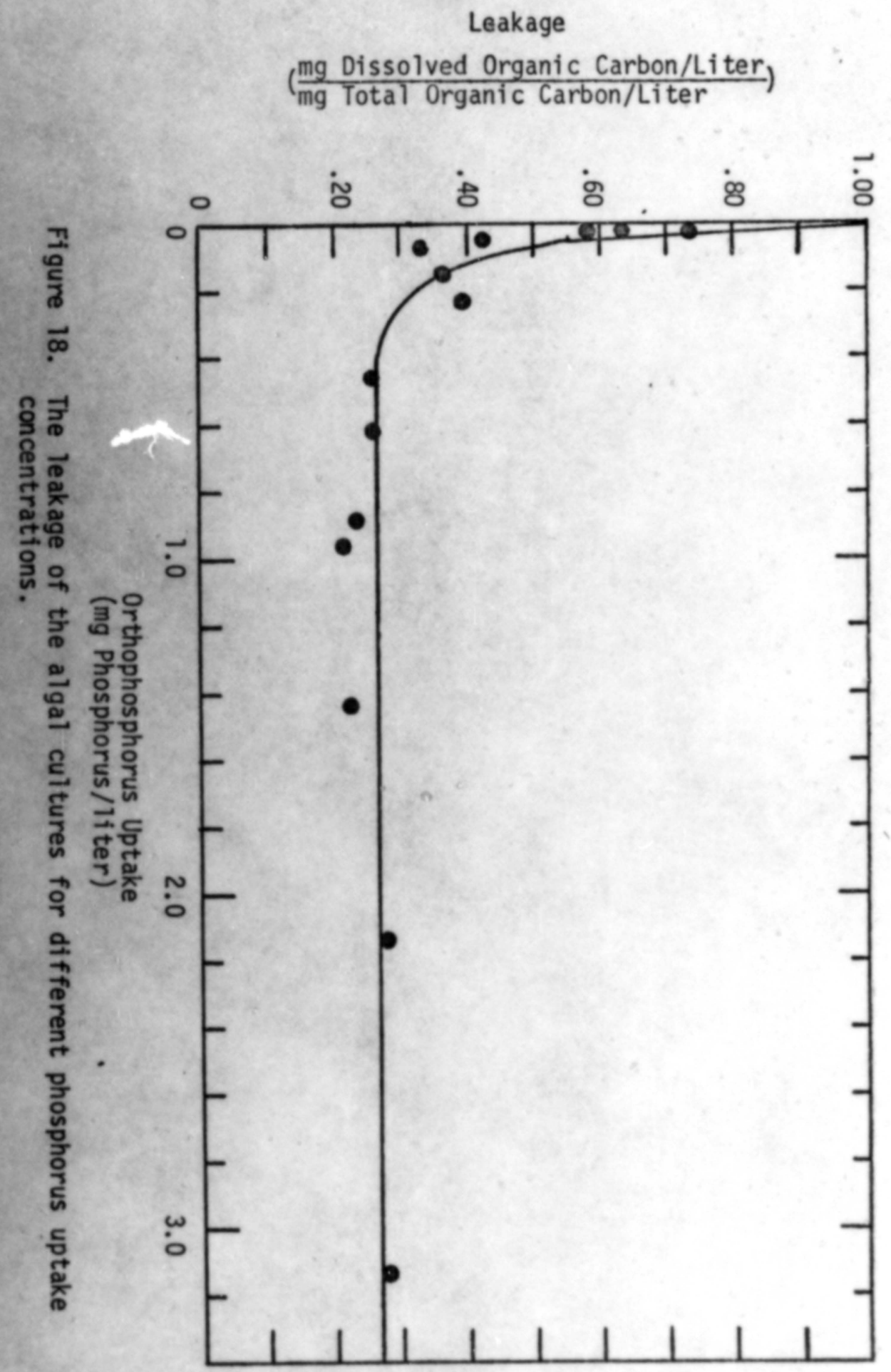


cell wall to the environment. Consequently, low phosphorus availability would appear to explain the organic carbon leakage from algal cells noted in this study.

Algal Cell Conversion Efficiency. By calculating the ratio of maximum measured particulate organic carbon to maximum measured organic carbon a measurement for algal conversion efficiency can be derived for each algal culture. Algal conversion efficiency is defined as the ability of algae to convert photosynthetically produced organic carbon to algal cell protoplasm. Figure 19 shows the relation of plant conversion efficincy to orthophosphorus uptake, reflecting the importance of phosphorus availability. Clearly conversion efficiency suffers at low orthophosphorus uptake values. At high orthophosphorus uptake values, conversion efficiency is a constant 74 percent. This compares favorably with the 78 percent efficiency derived from the difference between types of carbon fixed measurements.

The point at which the algae establish a constant conversion efficiency is at $0.40 \mathrm{milligrams}$ of orthophosphorus uptake per liter.. From Figure 16 a phosphorus uptake of $0.40 \mathrm{mg} P / 1$ ter again yields a $C: P$ ratio of $C_{F 220}: P_{1}$. This represents the approximate carbon to phosphorus ratio at which the carbon limit shifts to a phosphorus limit. Therefore, in a region of phosphorus limitation, algal conversion efficiency declines with declining phosphorus availability.

Figures 11 and 12 revealed a linear relationship between carbon fixed by the algae and photosynthetic activity. In the phosphorus limited region, large quantities of the carbon fixed are lost to the 


\section{Efficiency}

$\left(\frac{\mathrm{mg} \text { Particulate Organic Carbon/liter }}{\mathrm{mg} \text { Total Organic Carbon/liter }}\right)$

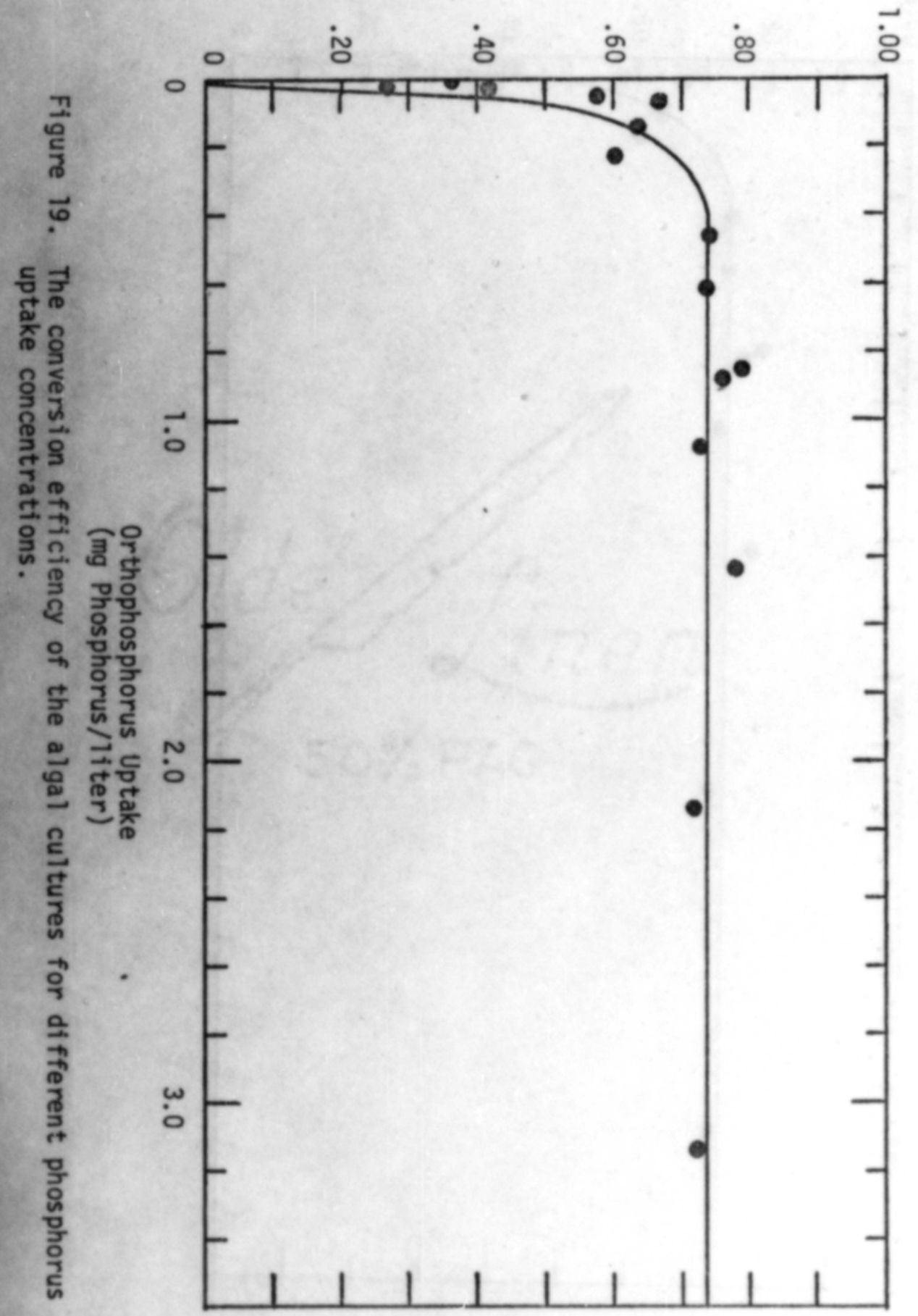


environment due to cell leakage. Because the photosynthetic process is in part the transformation of light energy to energy available to cellular metabolism, the loss of organic carbon through cell leakage represents loss of energy and potential algal biomass from the cell. Consequently at low orthophosphorus uptake values and at low algal efficiencies, the algae are limited in their ability to increase biomass.

\section{Algal Growth Potential}

The data clearly indicate that small amounts of available phosphorus in the form of orthophosphorus result in extremely high algal production, provided all other necessary nutrients and light are available in excess. Although a maximum $C: P$ ratio was not established with any accuracy in this study, it can be stated that algae with a $C_{F}: P$ ratio greater than about $C_{F 217}: P_{1}$ or a $C_{P}: P$ ratio greater than about $\mathrm{C}_{\mathrm{P} 177}: \mathrm{P}_{1}$ are limited in their ability to continue production. The C:P ratio at which an algae can maintain an algal bloom is undetermined from this study. However, as the ratio increases above $C_{F_{2} 17}: P_{1}$ and $C_{P_{177}}: P_{1}$ the ability of algae to sustain a bloom should be significantly reduced.

Growth Potential With Regards to Phosphorus Removal Method. An important part of this investigation was to determine what effect, if any, the different forms of phosphorus removal had on potential algal production. Evaluation of Figures 13, 14, 15, 16 and 17, clearly 
indicates the different removal techniques shows no difference in response. Table 2 shows each removal technique removed approximately the same percentage of total phosphorus as orthophosphorus. Algae apparently use only orthophosphorus. Therefore algal growth potential would not be affected by the removal technique used.

Investigation of the data did reveal that the lime removal technique followed by recarbonation caused in increase in inorganic carbon with a corresponding increase in the bicarbonate-carbon alkalinity. In flasks where there was adequate phosphorus available and a carbon limit, such increases in bicarbonate-carbonate alkalinity resulted in an increase in algal production. Conversely, in flasks where there was a phosphorus limit, the increase in alkalinity had no effect on algal production. It follows that lime treatment for phosphorus removal should only be used in a treatment facility where the effluent is discharged to a phosphorus limited body of water. Discharge of effluent treated with lime to remove phosphorus into a carbon limited environment would result in increased algal productivity.

In a phosphorus limited lake, discharge of a waste plant effluent without tertiary phosphorus removal will accelerate eutrophication. While there are usually many other sources of phosphorus available to a lake, a waste plant's contribution is extremely significant. Consequently, phosphorus removal by tertiary treatment would slow the process of eutrophication a meaningful amount in the phosphorus limited environment. 


\section{CONCLUSIONS}

From the results of this investigation the following conclusions can be made:

1. Treatment of a municipal waste treatment plant effluent containing phosphorus with either alum, an iron salt, or lime will remove phosphorus from that effluent.

2. Orthophosphorus appears to be the form of phosphorus most available to algae.

3. There is an optimum ratio of carbon to phosphorus for algae.

4. The optimum carbon to phosphorus ratio of algae depends on the form of carbon measurement used. Calculated carbon fixed values can be derived that include the organic carbon leaked from algal cells while measured particulate organic carbon values are available directly from laboratory measurements.

5. The optimum ratios for the two forms of carbon fixed values are $C_{F_{217}}: P_{1}$ and $C_{P_{177}}: P_{1}$.

6. At carbon to phosphorus ratios above the optimum, algae progressively leak more organic carbon and become progressively less efficient in converting carbon to biomass. 
51

7. Assuming sufficient availability of carbon, algal growth potential is directly related to available phosphorus.

8. The method of phosphorus removal does not effect algal growth potential provided a phosphorus limit is present. However, lime treatment would cause increased algal production in water with a carbon limit. 
1. Water Quality Criteria, Report of the Nations Technical Advisory Committee to the Secretary of the Interior, Federal Water

Pollution Control Administration, Washington, D. C. April 1, 1968, p. 55 .

2. Gerloff, G. C., "Evaluating Nutrient Supplies for the Growth of Aquatic Plants in Natural Waters," Proceedings of a National Academy of Sciences Symposium, Washington, D. C. 1969, p. 547.

3. Mackereth, F. J., "Phosphorus Utilization by Asterionella Formosa Hass, Journal of Experimental Botany, Vol. 4, 1958, pp. 296-313.

4. Standard Methods for the Examination of Water and Waste Water, 12th Edition, American Public Health Association, 1790 Broadway, New York, N. Y., 1965.

5. Keveran, N. R. and Ball, R. C., "Primary Productivity and Energy Relationships in Artificial Streams", Limnology and Oceanography, Volume 10, January, 1965, pp. 74-87.

6. FWPCA Methods for Chemical Analys is of Water and Wastes, U.S. Department of Interior Federal Water Pollution Control Administration Division of Water Quality Research Analytical Quality Control Laboratory, 1014 Broadway, Cincinnati, Ohio, November, 1969, pp. 223-232.

7. Stumm, Werner and Morgan, James J., Aquatic Chemistry, An Introduction Emphasizing Chemical Equilibria in Natural Waters, 1970, John Wi ley and Sons, Inc., New York, N. Y. p. 429. 
53

8. King, Darrell L., "The Role of Carbon in Eutrophication", Journal of the Water Pollution Control Federation, Vol. 42, December, 1970, pp. 2035-2051.

9. Bush, K., "Kolsyre Jamuikten I Bacltiskah Aust", Fennia, Vol. 68, May, 1945, pp. 1-208.

10. Hellebust, J. A., "Excretion of Some Organic Compounds by Marine Phytoplankton", Limnology and Oceanography, Vol. 10, April, 1965, p. 192.

11. Meyer, B. S. and Anderson, D. B., Plant Physiology, 1952, Duran Nostrand Company, Inc., Princeton, New Jersey, pp. 479-480. 
APPENDIX I

The inorganic growth media contained the following.

$\begin{array}{lc}\text { Chemical Compound } & \mathrm{mg} / 1 \text { iter } \\ \text { Sodium Bicarbonate } \mathrm{NaHCO}_{3} & 168.0 \\ \text { Potassium Nitrate } \mathrm{KNO}_{3} & 114 \\ \text { Ferric Chloride } \mathrm{FeCl}_{2} & 4.0 \\ \text { Calcium Chloride } \mathrm{CaCl}_{2} & 43.3 \\ \text { Microelements* } & 1 \mathrm{mg} / 1 \text { iter } \\ \text { EDTA } & 5 \mathrm{mg} / 1 \text { iter }\end{array}$

*Stock solution of micronutrients:

$\mathrm{mg} / 1$ iter

$\begin{array}{ll}\mathrm{H}_{3} \mathrm{BO}_{3} & 2.86 \\ \mathrm{MnCl}_{2} \cdot 4 \mathrm{H}_{2} \mathrm{O} & 1.81 \\ \mathrm{ZnSO}_{4} \cdot 7 \mathrm{H}_{2} \mathrm{O} & 0.22 \\ \left(\mathrm{NH}_{4}\right)_{6} \mathrm{M}_{07} \mathrm{O}_{24} \cdot 4 \mathrm{H}_{2} \mathrm{O} & 0.18 \\ \mathrm{CuSO}_{4} & 0.05 \\ \mathrm{Co}\left(\mathrm{NO}_{3}\right)_{2} \cdot 6 \mathrm{H}_{2} \mathrm{O} & 0.49\end{array}$


University Libraries

University of Missouri

Digitization Information for Theses and Dissertations project. Scanned from microfilm; no subsequent editing done.

Local identifier

Source information

Identifier

Format

Content type

Notes

Capture information

Date captured

Scanner manufacturer/model ScanPro 3000 /e-ImageData

Scanning software

Optical resolution

Compression

Color settings

File types

Notes

Derivatives - Access copy

Editing software

Resolution

Color

File types

Notes
Vogel1971

Microfilm reel\# T210-215

Microfilm

Text

2018

PowerScan $3000(\mathrm{TM})$ v5.341

$600 \mathrm{dpi}$

LZW

bitonal

tiff

Scanned from microfilm; no editing done.

Photoshop

600 dpi

grayscale

pdf

Converted from tiff to pdf using Adobe Acrobat Pro DC. 